\title{
JULIANA YAMASHIRO
}

Eficácia dos medicamentos imunomoduladores no tratamento da mielopatia associada ao HTLV-1/paraparesia espástica tropical (HAM/TSP): revisão sistemática

Dissertação apresentada à Faculdade de Medicina da Universidade de São Paulo para obtenção do título de Mestre em Ciências

Programa de Doenças Infecciosas e Parasitárias

Orientador: Prof. Dr. Aluisio Augusto Cotrim Segurado 


\section{Dados Internacionais de Catalogação na Publicação (CIP)}

Preparada pela Biblioteca da

Faculdade de Medicina da Universidade de São Paulo

Creprodução autorizada pelo autor

Yamashiro, Juliana

Eficácia dos medicamentos imunomoduladores no tratamento da mielopatia associada ao HTLV-1/paraparesia espástica tropical (HAM/TSP): revisão sistemática / Juliana Yamashiro. -- São Paulo, 2013.

Dissertação(mestrado)--Faculdade de Medicina da Universidade de São Paulo. Programa de Doenças Infecciosas e Parasitárias.

Orientador: Aluisio Augusto Cotrim Segurado.

Descritores: 1.Vírus 1 linfotrópico T humano 2.Paraparesia espástica tropical/terapia 3.Interferon alfa 4.Zidovudina 5.Lamivudina 6.Ensaios clínicos controlados randomizados como assunto 7.Revisão sistemática

USP/FM/DBD-428/13 


\section{AGRADECIMENTOS}

Ao Prof. Dr. Aluisio Augusto Cotrim Segurado, pela orientação, pelo estímulo durante a residência médica e realização dessa dissertação, e idealismo com que me ensinou sobre o HTLV.

Ao Prof. Dr. Wanderley Marques Bernardo, ao Prof. Dr. Moacyr Roberto Cuce Nobre e à Valéria Vilhena, pela orientação das questões metodológicas desta dissertação.

À Roseli Antonia Santos, pelo apoio que sempre ofereceu independentemente do Programa de Pós-Graduação em Doenças Infecciosas e Parasitárias da FMUSP.

À Faculdade de Medicina de Marília - Famema, responsável pela minha formação acadêmica e pelo ensino da Medicina baseada em evidência.

Aos funcionários do Ambulatório de Moléstias Infecciosas e Parasitárias do Hospital das Clínicas da Faculdade de Medicina da Universidade de São Paulo e aos pacientes do ambulatório de HTLV, pela aprendizagem.

Aos meus queridos amigos e à minha família, pela compreensão e paciência durante o período de realização deste trabalho. 


\section{NORMATIZAÇÃO ADOTADA}

Esta dissertação está de acordo com as seguintes normas, em vigor no momento desta publicação:

Referências: adaptado de International Committee of Medical Journals Editors (Vancouver).

Universidade de São Paulo. Faculdade de Medicina. Divisão de Biblioteca e Documentação. Guia de apresentação de dissertações, teses e monografias. Elaborado por Anneliese Carneiro da Cunha, Maria Julia de A. L. Freddi, Maria F. Crestana, Marinalva de Souza Aragão, Suely Campos Cardoso, Valéria Vilhena. 3a ed. São Paulo: Divisão de Biblioteca e Documentação; 2011.

Abreviaturas dos títulos dos periódicos de acordo com List of Journals Indexed in Index Medicus. 


\section{LISTA DE ABREVIATURAS E SIGLAS}

\section{LISTA DE FIGURAS}

\section{LISTA DE QUADROS}

\section{LISTA DE TABELAS}

\section{RESUMO}

\section{SUMMARY}

1 INTRODUÇÃO COM REVISÃO DE LITERATURA ..................................

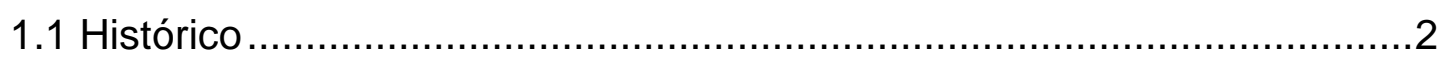

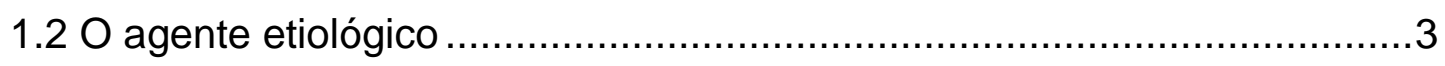

1.3 Epidemiologia da infecção por HTLV-1 ..........................................

1.3.1 Distribuição geográfica e prevalência .............................................10

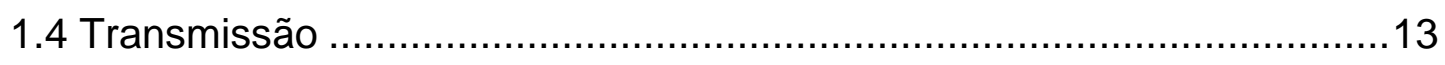

1.5 Patogênese da infecção por HTLV-1 .............................................. 14

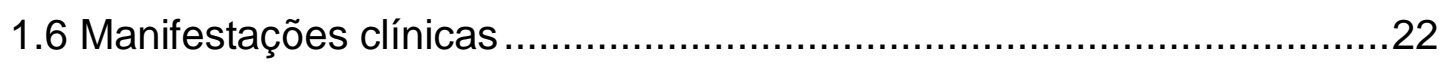

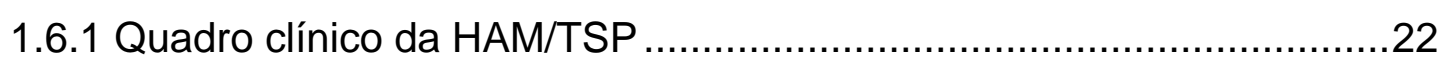

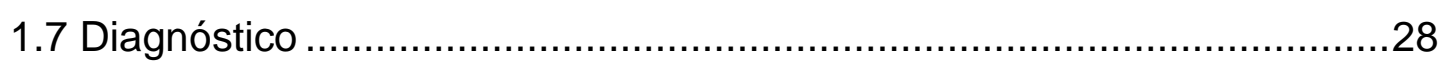

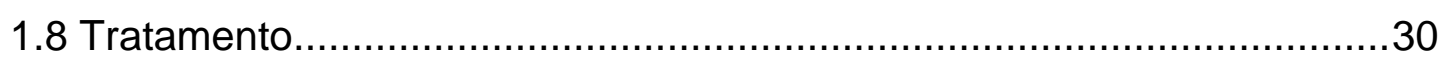

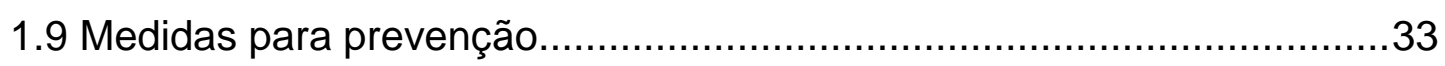

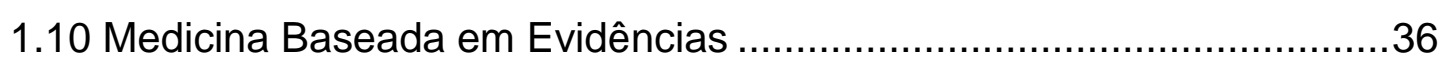

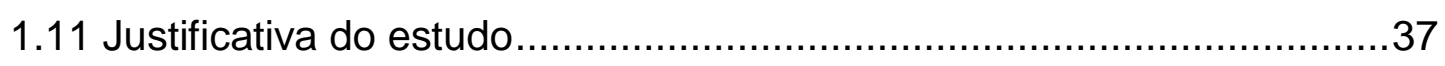

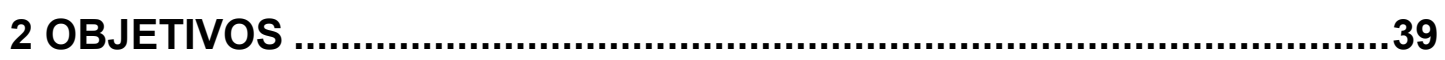

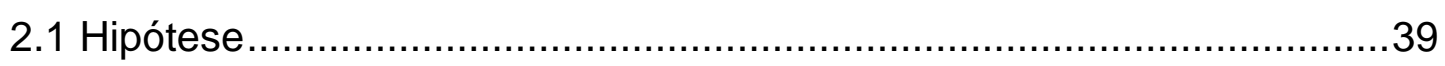

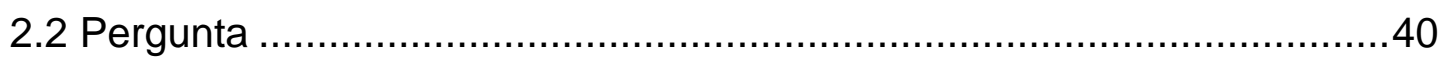

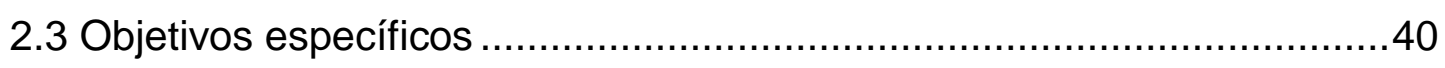

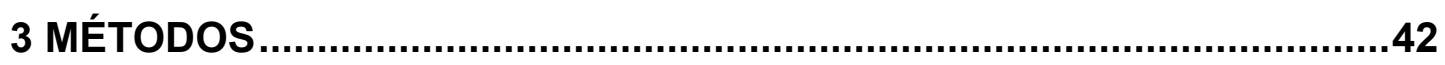

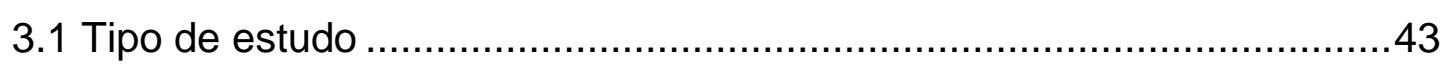

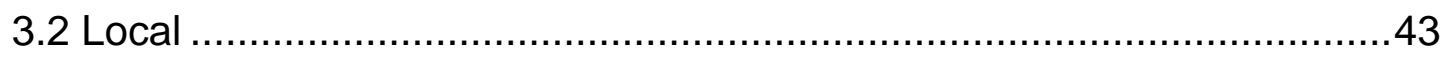

3.3 Tipos de participantes envolvidos nos estudos ....................................44

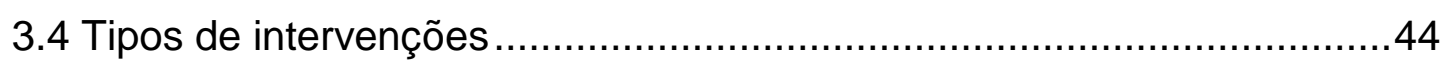

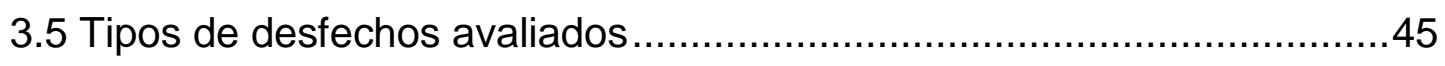


3.5.1 Desfechos primários .45

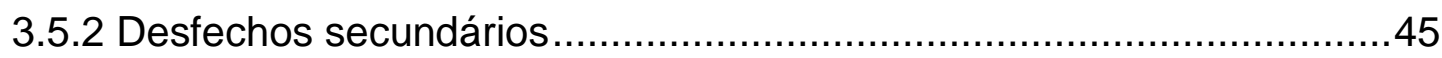

3.6 Estratégia de busca para identificação dos estudos ...............................46

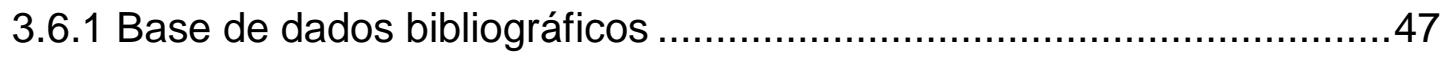

3.6.2 Descritores e palavras-chave ............................................................ 49

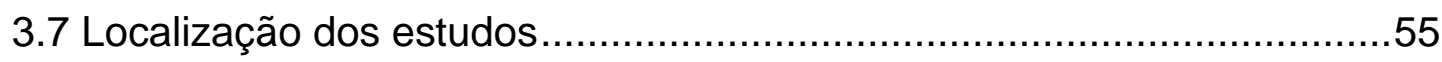

3.8 Avaliação da qualidade metodológica dos estudos .................................57

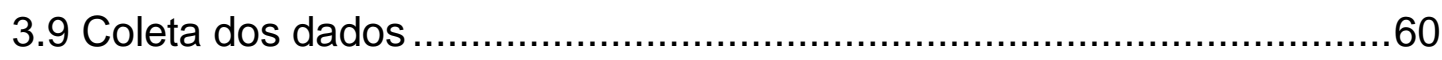

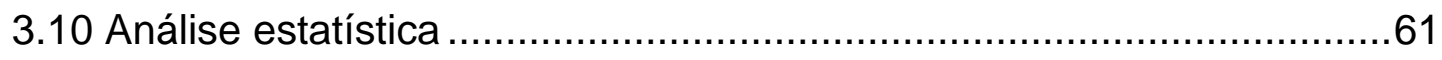

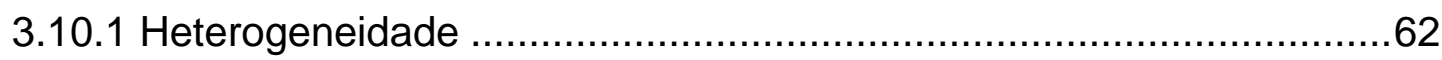

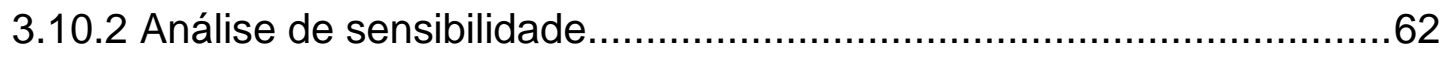

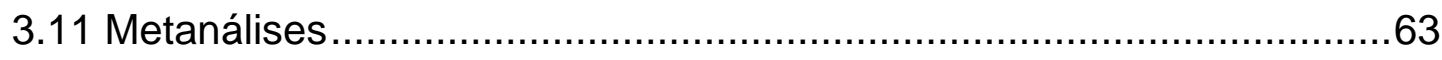

3.12 Atualização e aprimoramento da revisão sistemática ...........................63

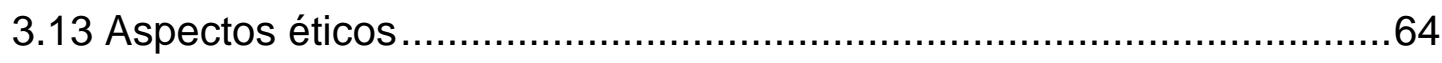

4 RESULTADOS

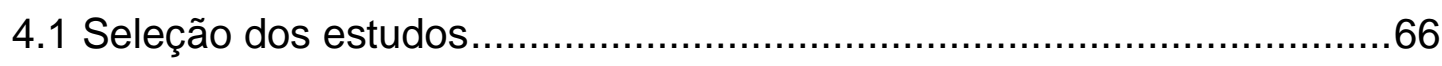

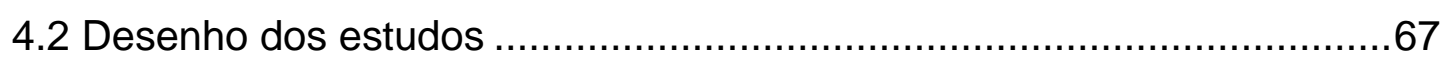

4.3 Tipos de desfechos mensurados, participantes e duração dos ECRs ....68

4.4 Validade interna dos estudos incluídos...............................................

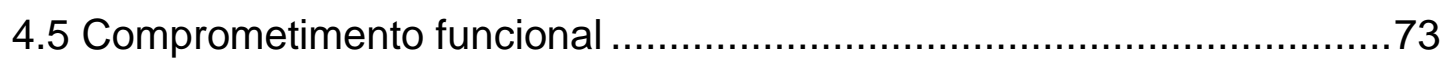

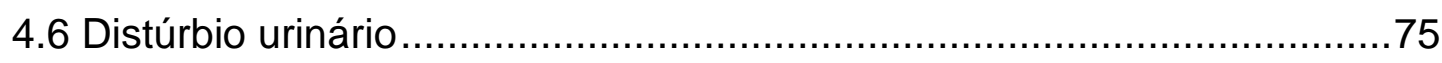

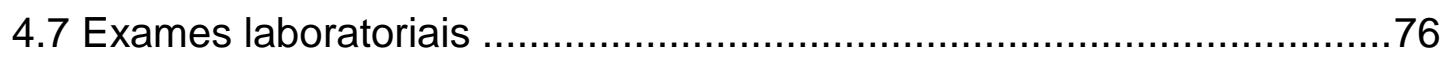

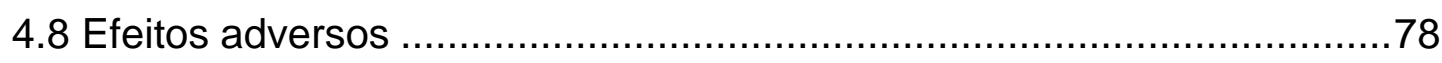

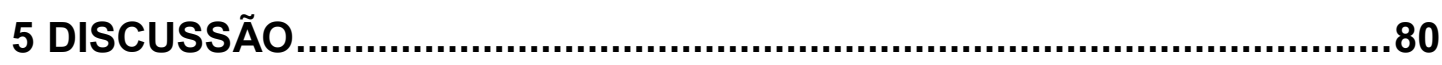

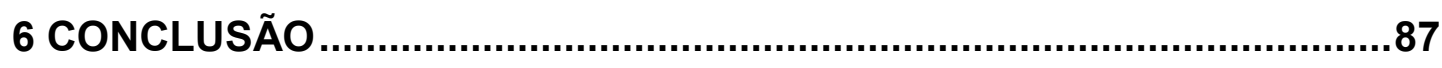

7 ANEXOS.

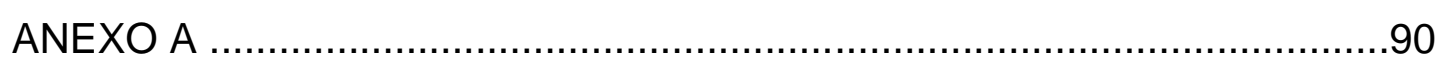

ANEXO B

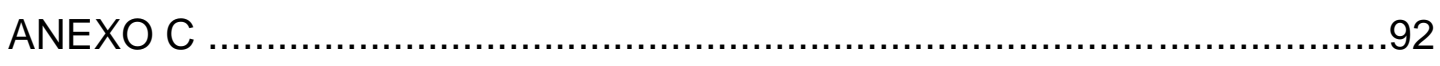

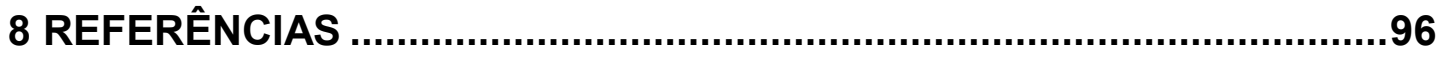




\section{LISTA DE ABREVIATURAS E SIGLAS}

\begin{tabular}{ll} 
ATLL & Leucemia/linfoma de células T do adulto \\
BVS & Biblioteca Virtual em Saúde \\
cDNA & DNA complementar \\
CTL & Linfócitos T CD8+ citotóxicos \\
DeCS & Descritores em Ciências da Saúde \\
DNA & Ácido desoxirribonucleico \\
ECRs & Ensaios clínicos randomizados e controlados \\
ELISA & Ensaio imunoenzimático \\
Embase & Excerpta Medica Database \\
et al. & E outros \\
GLUT-1 & Proteína transportadora de glicose do tipo-1 \\
GM-CSF & Fator estimulante de colônias de macrófago-granulócito \\
Gp & Glicoproteína \\
HAM & Mielopatia associada ao HTLV-1 \\
HBZ & Fator HTLV-1 bZIP (basic leucine zipper) \\
HLA & Antígeno leucocitário humano \\
hnRNP-A1 & Ribonucleoproteína nuclear heterogênea \\
HTLV & Vírus linfotrópico de células T humanas \\
Ho & Hipótese nula \\
H & Hipótese alternativa \\
ICAM-1 & Molécula 1 de adesão intercelular \\
IFN-Y & Interferon-gama \\
IgG & Imunoglobulina de classe G \\
IgM & Imunoglobulina de classe M \\
IL & Interleucina \\
IL-2Ra & Cadeia alfa do receptor para IL-2 \\
LCR & Líquido cefalorraquidiano \\
LFA-1 & Antígeno associado à função leucocitária tipo-1 \\
LILACS & Literatura Latino-Americana e do Caribe em Ciências da \\
& Saúde \\
\hline ing &
\end{tabular}




\begin{tabular}{ll} 
LTR & Sequência nucleotídica terminal repetitiva longa \\
MEDLINE & Medical Literature Analysis and Retrieval System Online \\
MeSH & Medical Subject Headings \\
MHC-I & Complexo principal de histocompatibilidade de classe I \\
mRNA & RNA mensageiro \\
MS & Ministério da Saúde \\
MTOC & Centro organizador de microtúbulos \\
NF-KB & Fator nuclear kappa B \\
NLM & National Library of Medicine \\
Nm & Nanômetro \\
OMS & Organização Mundial de Saúde \\
ORFs & Fases de leitura aberta \\
PCR & Reação em cadeia por polimerase \\
PDGF & Fator de crescimento derivado de plaqueta \\
PTHrP & Proteína relacionada ao hormônio da paratireoide \\
RFLP & Polimorfismo dos comprimentos dos fragmentos de restrição \\
RPG & Glicoproteína recombinante \\
RNA & Ácido ribonucleico \\
rT-PCR & Reação em cadeia por polimerase em tempo real \\
STLV & Vírus linfotrópico de células T de símios \\
TGF- $\beta 1$ & Fator de transformação de crescimento - beta 1 \\
TNF & Fator de necrose tumoral \\
TNF- $\alpha$ & Fator de necrose tumoral-alfa \\
TNF- $\beta$ & Fator de necrose tumoral-beta \\
TSP & Paraparesia espástica tropical \\
UDIV & Usuário de droga intravenosa \\
UI & Unidades internacionais \\
USP & Universidade de São Paulo \\
VPN & Virtual Private Network \\
WB & Western blot \\
\hline
\end{tabular}




\section{LISTA DE FIGURAS}

Figura 1 Representação esquemática da estrutura do vírion de HTLV-1

Figura 2 Representação esquemática da organização genômica do HTLV-1

Figura 3 Origem, disseminação geográfica e prevalência da infecção por HTLV-1

Figura 4 Representação esquemática da sinapse viral

Figura 5 A interação entre o linfócito T CD4+ infectado e o linfócito T CD8+ indica como a infecção pelo HTLV-1 pode conduzir a diferentes desfechos clínicos.

Figura 6 Hipótese da "Citotoxicidade Direta" .......................................19

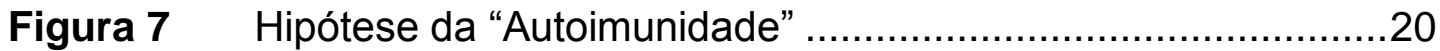

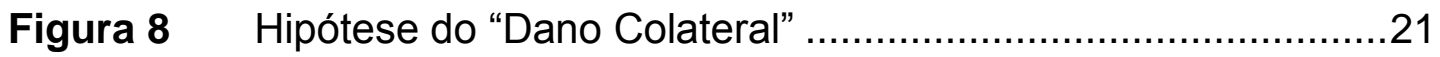

Figura 9 Representação esquemática do complexo neurológico do HTLV-1

Figura 10 Estratégia LILACS - clusters via BIREME de busca para ensaios clínicos randomizados e controlados

Figura 11 Estratégia EMBASE - Advanced Limits de busca para ensaios clínicos randomizados e controlados.

Figura 12 Estratégia Cochrane - Limits de busca para ensaios clínicos randomizados e controlados .55

Figura 13 Fluxograma da estratégia da revisão sistemática .56

Figura 14 Níveis de Evidência Científica segundo a classificação de Oxford Centre for Evidence-Based of Medicine 58

Figura 15 Fluxograma dos resultados da busca e seleção dos ECRs.....66 


\section{LISTA DE QUADROS}

Quadro 1 Critérios clínicos e laboratoriais da OMS para definição $\mathrm{HAM} / \mathrm{TSP}$

Quadro 2 Descrição dos componentes do P (pacientes com

HAM/TSP) e I (terapêutica de interesse) do acrônimo EPICOT

Quadro 3 Estratégia MEDLINE via PubMed de busca para ensaios clínicos randomizados e controlados

Quadro 4 Estratégia MEDLINE - Clinical Queries via PubMed de busca para ensaios clínicos randomizados e controlados

Quadro 5 Estratégia LILACS via BIREME de busca para ensaios clínicos randomizados e controlados

Quadro 6 Estratégia EMBASE de busca para ensaios clínicos randomizados e controlados

Quadro 7 Estratégia Cochrane de busca para ensaios clínicos randomizados e controlados

Quadro 8 Estudos excluídos da revisão sistemática após reunião e decisão consensual 


\section{LISTA DE TABELAS}

Tabela 1 Proteínas que compõem o HTLV-1 e respectivas funções........9

Tabela 2 Síntese das características dos clínicos randomizados e controlados de imunomoduladores para o tratamento de HAM/TSP.....

Tabela 3 Síntese da análise da validade interna dos ensaios clínicos randomizados e controlados de imunomoduladores para o tratamento de HAM/TSP 


\section{RESUMO}

Yamashiro J. Eficácia dos medicamentos imunomoduladores no tratamento da mielopatia associada ao HTLV-1/paraparesia espástica tropical (HAM/TSP): revisão sistemática [dissertação]. São Paulo: Faculdade de Medicina, Universidade de São Paulo; 2013.

INTRODUÇÃO: A mielopatia associada ao HTLV-1/paraparesia espástica tropical (HAM/TSP) é a manifestação neurológica mais descrita da infecção pelo HTLV-1. Embora o risco de seu desenvolvimento ao longo da vida do portador dessa retrovirose seja pequeno, $2 \%$ a $5 \%$, tal afecção pode causar um importante comprometimento funcional e prejuízo na qualidade de vida. Dadas as exigências atuais por melhores cuidados de saúde, os profissionais de saúde frequentemente empregam diferentes terapêuticas disponíveis para tratar pacientes com HAM/TSP, dentre os quais se destacam as drogas imunomoduladoras, visando reduzir a incapacidade e melhorar a qualidade de vida dos pacientes acometidos. Porém, ainda não há consenso sobre qual seria a melhor intervenção e, quando indicado, qual o melhor imunomodulador para o tratamento da HAM/TSP. MÉTODOS: Com - propósito de buscar-se evidência da eficácia dos medicamentos imunomoduladores no tratamento da HAM/TSP, foi conduzida uma revisão sistemática de ensaios clínicos randomizados e controlados nas bases de dados MEDLINE, LILACS, Embase e Registro Cochrane de Ensaios Clínicos Controlados. Selecionaram-se estudos relevantes, sem restrição de idioma e publicados até em 31/01/13. Além disso, foi realizada busca manual das referências bibliográficas dos estudos selecionados. RESULTADOS: Três ensaios clínicos randomizados e controlados que preencheram os critérios de inclusão foram analisados: dois deles abordando a eficácia do interferon a e um de zidovudina associada à lamivudina. CONCLUSÕES: Os pacientes que receberam 3,0 milhões de UI de interferon $\alpha$, pela via intramuscular, uma vez por dia, durante 28 dias consecutivos, apresentaram melhora temporária do comprometimento funcional e do distúrbio urinário, quando comparados aos que receberam 0,3 ou 1,0 milhão de UI de interferon $\alpha$, e apresentaram efeitos adversos toleráveis e temporários. A intensidade da melhora e o tempo do benefício dependeram do grau de comprometimento funcional e urinário prévio ao estudo. Os pacientes que receberam $300 \mathrm{mg}$ de zidovudina e $150 \mathrm{mg}$ de lamivudina, pela via oral, duas vezes por dia, durante 24 semanas, não apresentaram melhora significativa do comprometimento funcional, da dor em membros inferiores ou do distúrbio urinário, quando comparados aos pacientes que receberam placebo. A literatura revisada mostrou-se escassa e heterogênea no que se refere às drogas utilizadas e à dosagem, bem como nos desfechos clínicos avaliados. Em função disso, não se realizou metanálise. Conclui-se que não há 
evidência definitiva de eficácia do uso de imunomoduladores para o tratamento da HAM/TSP.

Descritores: Vírus 1 linfotrópico $\mathrm{T}$ humano; Paraparesia espástica tropical/terapia; Interferon alfa; Zidovudina; Lamivudina; Ensaios clínicos controlados randomizados com assunto; Revisão Sistemática. 


\section{SUMMARY}

Yamashiro J. Efficacy of immunomodulating drugs in the treatment of HTLV-1associated myelopathy/tropical spastic paraparesis (HAM/TSP): a systematic review [dissertation]. São Paulo: "Faculdade de Medicina, Universidade de São Paulo"; 2013.

BACKGROUND: HTLV-1-associated myelopathy/tropical spastic paraparesis (HAM/TSP) is the most frequently described neurological manifestation of this retroviral infection. Even through the lifetime risk of HTLV-1 carries developing HAM/TSP is low (2\% to $5 \%$ ) this condition may cause significant disability and compromise quality of life. Given current demands for better health care, health professionals often use different available therapies to treat patients with HAM/TSP, and, particularly, immunomodulating drugs to reduce disability and improve quality of life. However, so far there is no consensus about the best intervention, and, when recommended, the best immunomodulating drug for the treatment of HAM/TSP. METHODS: To establish whether there is evidence of the efficacy of immunomodulating drugs in the treatment of HAM/TSP. We conducted a systematic review of randomized, double-blind, controlled trials, searching MEDLINE, LILACS, EMBASE and the Cochrane Central Register of Controlled Trials. We selected relevant studies published until January 31st, 2013, regardless of language. In addition, a manual search of the references of selected studies was conducted. RESULTS: Three randomized controlled clinical trials that met our inclusion criteria were analyzed: two of them address the efficacy of interferon $\alpha$ and another of zidovudine plus lamivudine. CONCLUSIONS: Patients who received 3.0 million IU of interferon $\alpha$, intramuscularly, once a day, for 28 consecutive days, showed temporary improvement of functional impairment and urinary disorder, as compared to those who received 0.3 or 1.0 million IU of interferon $\alpha$, and exhibited with tolerable and temporary side effects. The intensity and duration of improvement depended on the degree of functional impairment and urinary disorder prior to the study. Patients who received $300 \mathrm{mg}$ zidovudine plus $150 \mathrm{mg}$ lamivudine, orally, twice a day, for 24 weeks showed no significant improvement in functional impairment, in lower limbs pain or in urinary disorder when compared to patients who received placebo. The literature we reviewed is scarce and heterogeneous in terms of used drugs and in evaluated clinical outcomes. Therefore, a metaanalysis was not performed. We concluded that there is no definitive evidence of the efficacy of imunnomodulating drugs in the treatment of $\mathrm{HAM} / \mathrm{TSP}$.

Descriptors: Human T-lymphotropic virus 1; Tropical spastic paraparesis/therapy; Interferon-alpha; Zidovudine; Lamivudine; Randomized trial; Systematic Review. 
1 INTRODUÇÃo COM REVISÃO DE LITERATURA 


\section{INTRODUÇÃO COM REVISÃO DE LITERATURA}

Neste capítulo, descrevem-se, inicialmente, os aspectos epidemiológicos, virológicos, patogenéticos e clínicos da infecção pelo vírus linfotrópico de células T humanas do tipo 1 (HTLV-1). Em seguida, revisamse as estratégias para compilação de resultados de estudos clínicos, com vistas à caracterização da evidência que deve nortear a tomada de decisão na prática clínica.

\subsection{Histórico}

É importante, inicialmente, apontar a evolução do conhecimento científico que relacionou a ocorrência de infecção por retrovírus e o desenvolvimento de doença humana.

Desde a década de 1970, vários casos de neoplasia hematológica de células T em adultos e de causa desconhecida foram investigados no Japão (Uchiyama et al., 1977) e, em 1979, a partir do estudo de um paciente com linfoma cutâneo de células $\mathrm{T}$ periféricas com características incomuns, o vírus linfotrópico de células T humanas (HTLV) foi isolado (Poiesz et al., 1980). O HTLV-1 foi, assim, o primeiro retrovírus humano descrito, tendo sido observado seu tropismo para linfócitos T (Matsuoka; Jeang, 2007). 
Por outro lado, quadros de doença neurológica degenerativas, denominada de paraparesia espástica tropical (TSP), são descritos no Caribe e Japão desde 1956 (Osame et al., 1986). Em conferência realizada pela OMS, em 1989, no Japão, concluiu-se que os quadros de paraparesia espástica detectados na Jamaica e Martinica, e os quadros de mielopatia no Japão eram causados pelo mesmo agente etiológico, o HTLV-1. A partir desse consenso, foi definida como nomenclatura única a denominação mielopatia associada ao HTLV-1/paraparesia espática tropiacal (HAM/TSP) para essa afecção neurológica (WHO, 1989). No Brasil, os primeiros casos da HAM/TSP foram relatados em 1989 (Castro-Costa et al., 1994).

\subsection{0 agente etiológico}

O HTLV-1 é um RNA vírus, tipo C, da família Retroviridae, subfamília dos Orthoretrovirinae, gênero Deltaretrovírus e o primeiro retrovírus associado ao câncer humano. Apresenta um envoltório composto por duas camadas lipídicas, com as glicoproteínas de superfície (a viral externa e a transmembrana), e contém a partícula viral de 100 nm de diâmetro, arredondada, cujo material genético é composto por duas fitas de RNA com polaridade positiva (Figura 1). O capsídeo apresenta simetria icosaédrica, e protege o RNA viral e as enzimas protease, transcriptase reversa e integrase (Verdonck et al., 2007; Kannian; Green, 2010). 


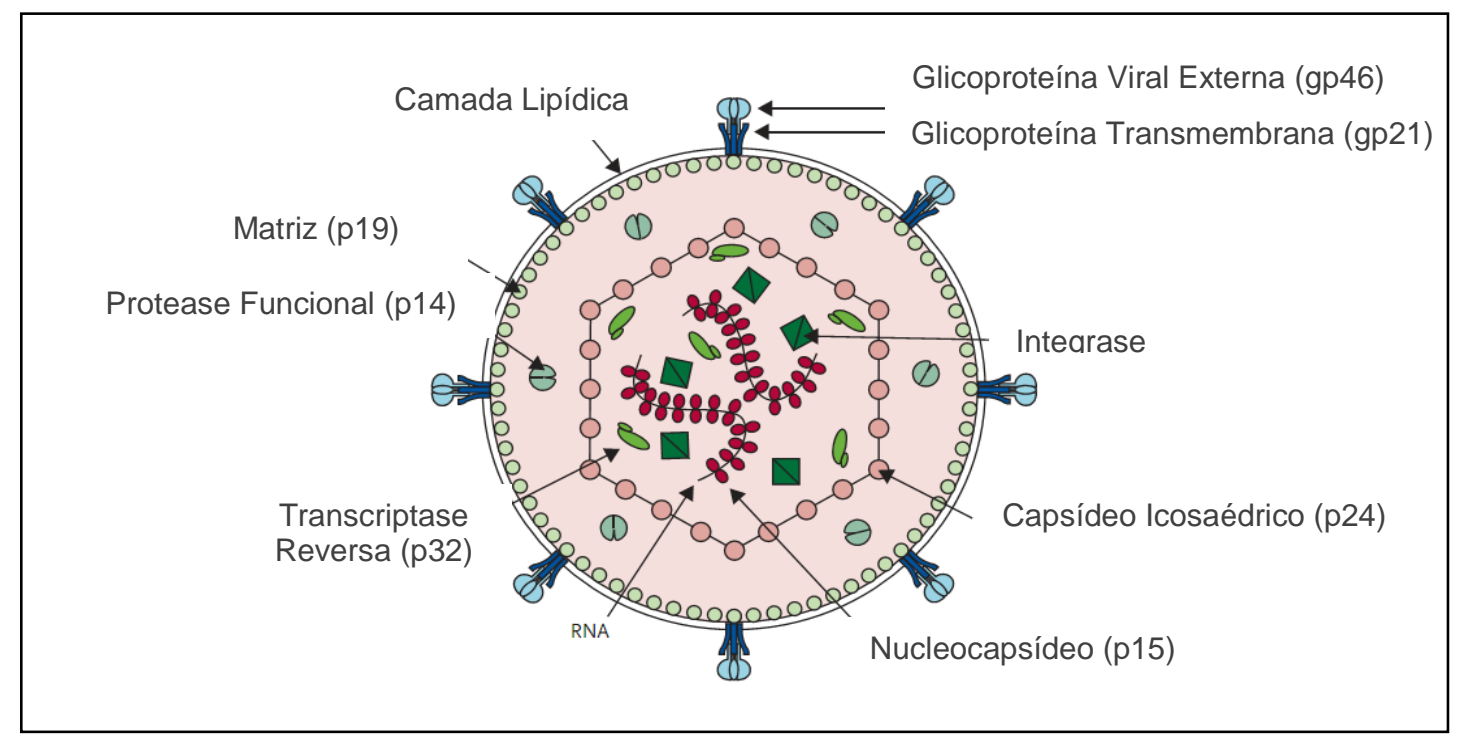

FONTE: Adaptado de Verdonck et al., 2007.

Figura 1 - Representação esquemática da estrutura do vírion de HTLV-1

Seu genoma possuiu uma estrutura similar a dos demais retrovírus, possuindo os segmentos descritos na Figura 2: gag, que codifica as proteínas do core dos retrovírus; pol, que codifica as enzimas necessárias para o ciclo replicativo; env, que codifica proteínas do envoltório; e $p X$, em 3', que codifica as duas principais proteínas regulatórias, Tax e Rex (Verdonck et al., 2007).

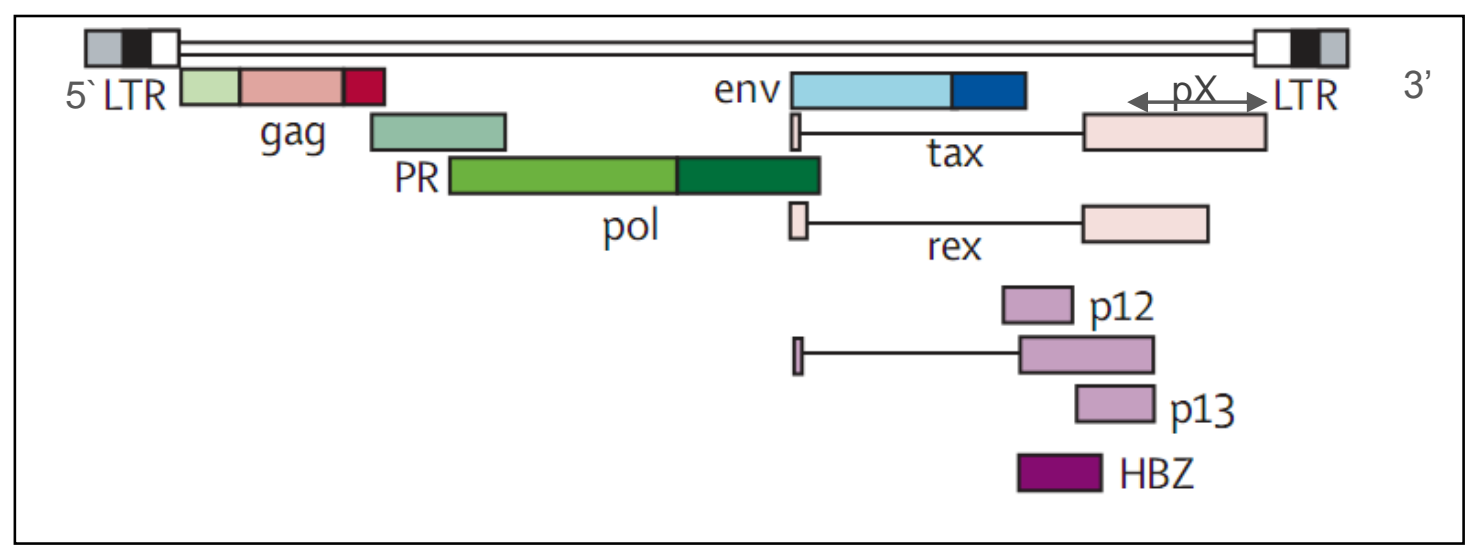

FONTE: Adaptado de Verdonck et al., 2007.

Figura 2 - Representação esquemática da organização genômica do HTLV-1 
As proteínas estruturais do core viral são as do nucleocapsídeo (p15), do capsídeo (p24) e da matriz (p19). Inicialmente, sintetizada com uma poliproteína precursora, essa é, posteriormente, clivada nos fragmentos finais: p19, p24 e p15. Relacionada à região gag está a síntese da enzima protease, cujo gene codificador estende-se da porção 3' da região gag até a porção 5' da pol. A protease sofre clivagem autocatalizada, gerando a molécula ativa responsável pelo processamento dos produtos dos genes gag e gag-pol. A porção 5' do gene pol é conhecida por codificar a enzima transcriptase reversa.

As proteínas do envoltório são as glicoproteínas transmembrana (gp21) e a viral externa (gp46). O produto de tradução da região codificadora do gene env é, inicialmente, sintetizado como poliproteína e, posteriormente, clivado em seus produtos finais, gp46 e gp21. Finalmente, as sequências nucleotídicas terminais repetitivas longas (LTRs), idênticas e localizadas nas extremidades 5' e 3' do genoma proviral, contêm sequências nucleotídicas regulatórias, que atuam na integração e expressão proviral (Verdonck et al., 2007; Matsuoka; Jeang, 2007; Kannian; Green, 2010).

A região $p X$ distingue o HTLV dos demais retrovírus pela codificação de proteínas com funções reguladoras de expressão e contém quatro pequenas fases de leitura aberta (Open Reading Frames - ORFs): pX-I, pXII, pX-III e pX-IV: 
- $\quad$ pX-I e pX-II: codificam as proteínas p12 e p30, respectivamente. São importantes no processo inicial de infecção e na persistência viral;

- $\quad$ pX-III: contém o gene rex que codifica a proteína p27 (Rex). Esta é uma proteína reguladora de expressão, responsável pela retroalimentação negativa, sendo sintetizada nas mesmas taxas que os demais produtos da replicação viral e, quando atinge níveis de concentração mais elevados, passa a inibir a transcrição de novas fitas de RNA mensageiro (mRNA). Esse mecanismo é capaz de regular os níveis de expressão dos genes codificadores dos componentes virais, determinando maior ou menor síntese dos vírions infectantes;

- $\quad$ pX-IV: contém o gene tax que codifica a proteína p40 (Tax). Esta é uma proteína indutora da transcrição viral, cujo subproduto, p40Tax, é responsável por ativar a transcrição do gene U3 na região de LTR, dando início ao processo de transcrição do provírus; Tax regula a transcrição do genoma proviral indiretamente, ao interagir com diferentes proteínas regulatórias celulares, e pode induzir, indiretamente, a expressão de genes celulares, tais como genes de citocinas e proto-oncogenes, como c-fos e c-erg. Esse mecanismo é importante na transformação da célula infectada pelo HTLV-1 e na patogenia de doenças associadas a essa infecção viral. Além disso, é um alvo antigênico de linfócitos T CD8+ citotóxicos (CTL) na resposta imune do 
hospedeiro ao HTLV-1 (Verdonck et al., 2007; Matsuoka; Jeang, 2007; Kannian; Green, 2010).

Polimorfismos no gene $p X$ podem influenciar a carga proviral circulante de HTLV-1 em decorrência de diferenças na habilidade de transativação da proteína Tax, ou pela diferença no reconhecimento do agente pelos CTLs. Diferenças na atividade de transativação no gene da citocina pela proteína Tax também podem influenciar a evolução clínica da infecção (Matsuoka; Jeang, 2007; Kannian; Green, 2010).

A proteína Tax induz o aumento da expressão de diferentes genes da célula eucariótica relacionados com a divisão celular, tais como os protooncogenes c-fos, c-myc, c-sis e c-erg; fatores de crescimento ou seus receptores, como, por exemplo, os que codificam a interleucina 1 (IL-1), IL-2, IL-3, IL-6, cadeia alfa do receptor para IL-2 (IL-2Ra), fator de crescimento derivado de plaqueta (PDGF), fator estimulante de colônias de macrófagogranulócito (GM-CSF), fator de crescimento tumoral beta (TGF- $\beta$ ), proteína relacionada ao hormônio da paratireoide (PTHrP), vimetina (proteína do citoesqueleto), complexo principal de histocompatibilidade de classe I (MHCI), fator nuclear kappa B (NF-KB) e fator de necrose tumoral beta (TNF- $\beta$ ). Além disso, contribui para a indução da transformação celular, ao interagir com genes supressores de tumores, especialmente $p 53$ e do retinoblastoma, e interferir nos mecanismos de apoptose. O único gene celular, até o momento descrito como tendo sua transcrição inibida pela Tax, é o gene que 
codifica a polimerase $\beta$, enzima envolvida no reparo do DNA (Verdonck et al., 2007; Matsuoka; Jeang, 2007; Kannian; Green, 2010).

A proteína Rex favorece o acúmulo de proteínas estruturais, em detrimento das proteínas regulatórias, e qualquer alteração entre a expressão e atividade de Tax e Rex pode modificar o estado de replicação viral nas células infectadas. Tax e Rex não apenas regulam a expressão viral, mas também podem interferir nas funções da célula hospedeira em diferentes níveis, afetando, como anteriormente mencionado, a transcrição e a tradução de vários genes celulares. Esses efeitos de Tax e Rex certamente são relevantes na patogênese das doenças associadas ao HTLV (Verdonck et al., 2007; Matsuoka; Jeang, 2007; Kannian; Green, 2010).

Outro segmento gênico do HTLV-1 de importância patogênica no desenvolvimento de ATLL é o HBZ (fator HTLV-1 bZIP). Ao contrário da expressão variável de Tax, a expressão de HBZ ocorre de modo uniforme nas células leucêmicas e inibe fatores de transcrição viral, inclusive Tax. Talvez a expressão de HBZ possa estimular a proliferação celular e inibir a expressão de Tax, o principal antígeno viral reconhecido pelas CTLs, dificultando o reconhecimento das células infectadas e favorecendo a sua persistência (Matsuoka; Jeang, 2007).

A Tabela 1 resume de forma esquemática as proteínas que compõem o HTLV-1 e suas respectivas funções (Verdonck et al., 2007; Matsuoka; Jeang, 2007; Kannian; Green, 2010). 
Tabela 1 - Proteínas que compõem o HTLV-1 e respectivas funções

\section{PROTEÍNAS}

Proteínas do envoltório (codificadas pelo

env)

glicoproteína viral externa (gp46)

glicoproteína transmembrana

(gp21)

Proteínas do core (codificadas por gag)

\author{
matriz (p19) \\ capsídeo (p24) \\ nucleocapsídeo (p15)
}

\section{Proteínas funcionais (codificadas por pol)}

\author{
protease $(\mathrm{p} 14)$ \\ transcriptase reversa $(\mathrm{p} 95)$ \\ Integrase
}

\section{Proteínas Regulatórias}

Tax

$\operatorname{Rex}$

p12

p30

p13

HTLV-1 bZIP-factor (HBZ) liga-se ao receptor da célula hospedeira

ancora a glicoproteína viral externa

organiza os componentes virais no interior da membrana celular

protege o RNA viral e as proteínas

proteína que se une ao ácido nucleico

cliva poliproteínas precursoras em proteínas maduras

sintetiza o DNA complementar ao RNA viral

facilita a inserção do provírus no genoma da célula do hospedeiro

ativa a transcrição do provírus e de genes da célula eucariótica

modula o transporte do RNA viral

ativa os linfócitos T

modula a transcrição viral

modula a função mitocondrial

modula a transcrição viral e inibe a expressão de Tax, permitindo a evasão de células infectadas do sistema imune

FONTE: Adaptado de Verdonck et al., 2007. 
Do ponto de vista genotípico, sabe-se que as regiões LTR e env do provírus de HTLV-1 apresentam uma grande variabilidade, enquanto as regiões gag e pol, mais conservadas, exibem alta similaridade entre diferentes isolados. Por essa razão, as sequências das regiões gag e pol são particularmente preteridas para a caracterização genotípica dos subtipos virais (Feuer; Green, 2005).

\subsection{Epidemiologia da infecção por HTLV-1}

\subsubsection{Distribuição geográfica e prevalência}

No mundo, estima-se que de 10 a 20 milhões de pessoas estejam infectadas pelo HTLV-1, sendo a infecção considerada endêmica no Sudoeste do Japão, Caribe, África Subsaariana, Melanésia e América do Sul (Catalan-Soares et al., 2005).

A análise filogenética da região LTR classifica o HTLV-1 em sete subtipos (a-g): HTLV-1a ou cosmopolita, endêmico em diferentes regiões geográficas na Europa, Sul da América do Norte e na América do Sul, incluindo o Brasil; HTLV-1b ou África Central, endêmico na África Central; HTLV-1c ou Áustralo-Melanésio, endêmico na Austrália e Papua-Nova Guiné; HTLV-1d, subtipo mais recentemente identificado na África Central; 
HTLV-1e, isolado em pigmeus Efe Mbuti vivendo no Congo; HTLV-1f, isolado em um indivíduo do Gabão; e HTLV-1g, isolado em moradores de áreas florestais na República dos Camarões (Catalan-Soares et al., 2005; Verdonck et al., 2007).

O subtipo cosmopolita consiste em quatro subgrupos: A transcontinental; B - japonês, endêmico no Japão e em áreas isoladas da América do Sul; C - África Ocidental; e D - Norte da África. O subgrupo transcontinental e da África Ocidental foram também confirmados em vários países americanos (Verdonck et al., 2007).

As hipóteses relativas à origem e à disseminação geográfica dessa retrovirose são baseadas em dados filogenéticos e antropológicos (Figura 3). Acredita-se que o vírus linfotrópico de células T de primatas (PTLV) tenha se originado de primatas não humanos africanos e migrado para Ásia, onde evoluiu para o vírus linfotrópico de células T de símios (STLV-1). No início, a linhagem STLV-1 disseminou-se para a Índia, Indonésia e Japão, e retornou para a África (flecha 1). Em seguida, cruzou a barreira símio-humana na Indonésia e esses humanos imigraram para a Melanésia, resultando no HTLV-1c (flecha 2). Na África, o STLV-1 caracterizou-se pela transmissão interespécies de HTLV-1a, HTLV-1b, HTLV-1d, HTLV-1e, HTLV-1f e HTLV$1 \mathrm{~g}$ (flecha 3). Por causa do tráfico de escravos e aumento dos deslocamentos de populações humanas, o HTLV-1 foi, posteriormente, introduzido na América, Japão e no Noroeste da África (flecha 4). As cores indicam a estimativa da prevalência da infecção por HTLV-1, baseada em vigilância de populações, estudos sorológicos sentinelas de gestantes e 
entre candidatos doadores de sangue. Em alguns países, a infecção pelo HTLV-1 é limitada a certos grupos populacionais ou áreas (Verdonck et al., 2007).

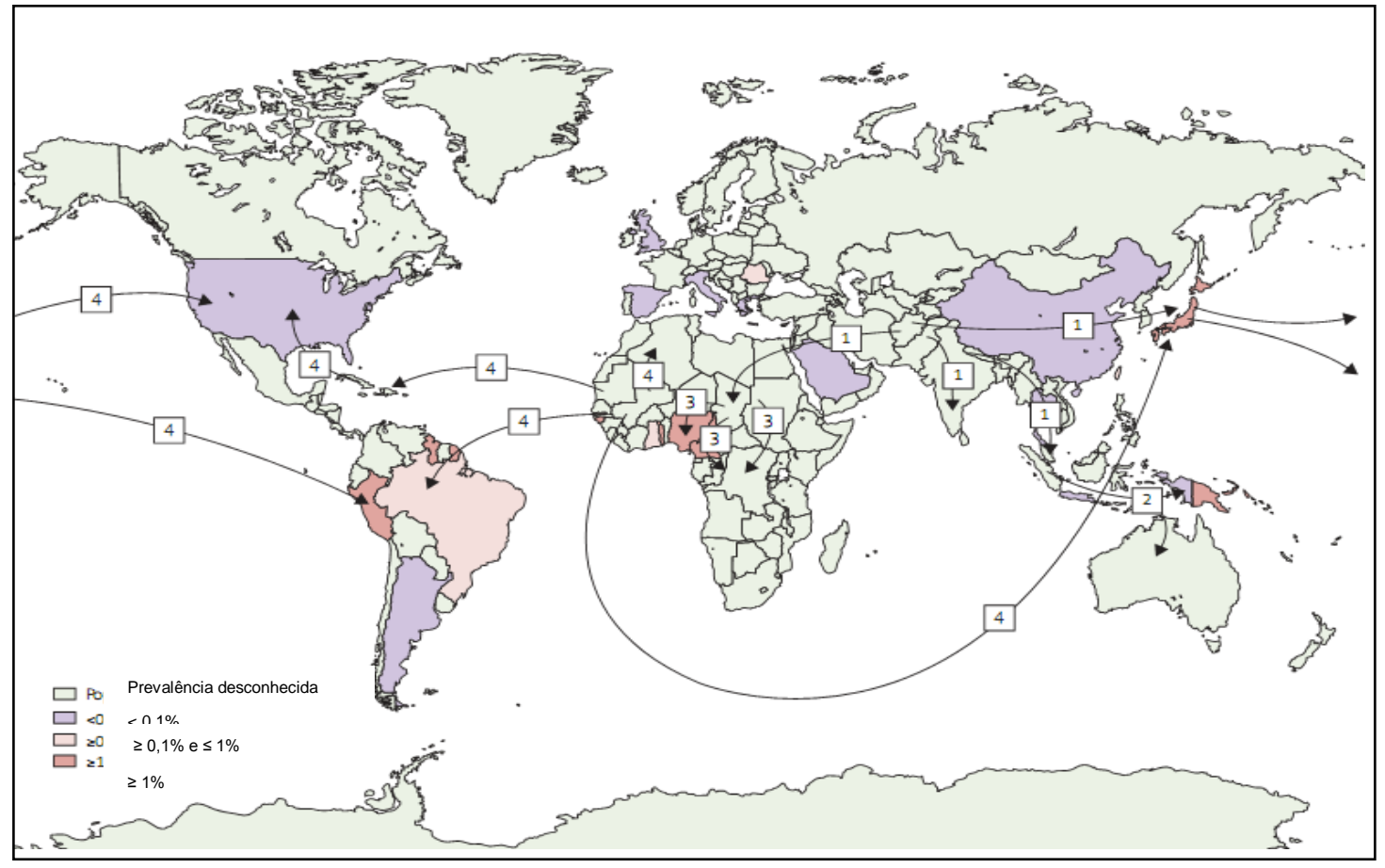

FONTE: Adaptado de Verdonck et al., 2007.

Figura 3 - Origem, disseminação geográfica e prevalência da infecção por HTLV-1

A soroprevalência da infecção pelo HTLV-1 é de até $37 \%$ no Sudoeste do Japão. De modo contrastante, entre candidatos a doador de sangue nos Estados Unidos e Canadá, a soroprevalência da infecção pelo HTLV-1 é baixa, variando de 0,01 a 0,03\%; no Brasil, de 1995 a 2000, a soroprevalência nesse grupo de indivíduos mostrou-se de 0,04\% em Santa Catarina, $0,32 \%$ em São Paulo, $0,94 \%$ na Bahia e $1 \%$ no Maranhão (Catalan-Soares et al., 2005). 


\subsection{Transmissão}

A transmissão viral pode ocorrer por via vertical, por contato sexual e pela via sanguínea. O risco do recém-nascido de mãe soropositiva para HTLV-1 ser infectado depende da carga proviral no leite materno, da duração do aleitamento e da compatibilidade dos antígenos leucocitários humanos (HLA) classe 1 entre a mãe e o recém-nascido. Estudos em populações endêmicas, como as que habitam o Sul do Japão, revelam taxa média de soroconversão com aleitamento materno entre $15 \%$ a $25 \%$, sendo essa a principal via de transmissão vertical do HTLV-1. A soroconversão dos conceptos via transmissão intrauterina e periparto é estimada como inferior a 5\% (Verdonck et al., 2007; Mylonas et al., 2010).

Com base nesses achados, no Japão e mais em alguns estados brasileiros, como Pernambuco, Mato Grosso do Sul e São Paulo, recentemente, o aleitamento artificial é recomendado para esses recémnascidos para diminuir o risco de transmissão do HTLV-1 a partir de mães soropositivas.

Os linfócitos infectados pelo HTLV-1 estão ainda presentes no sêmen e em secreções cervicovaginais, e podem, portanto, ser transmitidos em relações sexuais. Numa coorte de 10 anos com 30 casais sorodiscordantes acompanhados no estudo de Roucoux et al. (2005), a incidência de infecção do parceiro soronegativo foi estimada em 0,9 por 100 pessoas-ano (intervalo de confiança de $95 \%$ e 0,1 a 3,3 pessoas-ano) e verificou-se ser mais 
comum o homem infectado transmitir para a parceira susceptível (Verdonck et al., 2007).

O risco de profissionais de saúde em adquirir o vírus em um acidente com material pérfuro-cortante é baixo, restrito, principalmente, à exposição percutânea com agulhas contaminadas, devido à baixa carga proviral habitualmente encontrada em sangue periférico de portadores de infecção pelo HTLV-1 e pelo mecanismo de infecção ser dependente do contato célula a célula (Verdonck et al., 2007; Lairmore et al., 2011).

A transmissão de HTLV-1 por transfusão de sangue ocorre com transfusão de hemocomponentes celulares (concentrado de plaquetas, hemácias e leucócitos) e a soroconversão foi observada em $44 \%$ a $63 \%$ entre receptores de áreas endêmicas que receberam hemocomponentes celulares contaminados (Verdonck et al., 2007; Lairmore et al., 2011).

\subsection{Patogênese da infecção por HTLV-1}

O HTLV-1 pode infectar várias células, como linfócitos T e B, e células dendríticas, uma vez que o receptor que se associa a sua entrada nas células-alvo é a proteína transportadora de glicose tipo 1 (GLUT-1), presente em vários tipos celulares. Entretanto, o HTLV-1 exibe citotropismo preferencial para linfócitos T CD4+ e CD8+, com predomínio da infecção na subpopulação CD4+, pois a eficiência de sua entrada depende de 
proteoglicanas de heparan sulfato, moléculas que atuam como coreceptores e que estão presentes na superfície dos linfócitos T CD4+.

O receptor GLUT-1 participa do ciclo replicativo viral, ao possibilitar a fusão do envoltório do HTLV-1 com a membrana da célula-alvo, levando à interiorização do vírion no citoplasma. Ali ocorre a transcrição reversa do genoma viral de RNA em DNA complementar (cDNA) pela ação da enzima transcriptase reversa, translocação nuclear do cDNA e posterior inserção do genoma viral na célula eucariótica, pela ação da integrase viral. O genoma viral integrado passa a ser denominado DNA proviral e replica-se quando a célula sofre mitose. Após a integração, ocorre a transcrição dos genes virais, produzindo o RNA mensageiro (mRNA), capaz de codificar a síntese de reguladores da replicação viral, as proteínas Tax e Rex. As proteínas são sintetizadas no ribossomo a partir dos mRNAs e algumas são processadas após tradução, de modo a permitir montagem e liberação de novos vírions, levando parte da membrana celular para a formação dos envoltórios virais (Matsuoka; Jeang, 2007; Kannian; Green, 2010).

As proteínas do gag e env do HTLV-1 são despolarizadas nos linfócitos T isolados e a junção célula-célula ocorre após 40 minutos de contato. Quando uma célula infectada faz contato com uma célula não infectada, um centro organizador de microtúbulos (MTOC) é polarizado na junção célulacélula e a sinapse viral forma a interface. O complexo gag do HTLV-1 e o RNA genômico viral acumulam-se na sinapse e penetram na célula não infectada (Igakura et al., 2003). 
A Figura 4 ilustra também a sinapse viral, com ênfase no antígeno associado à função leucocitária tipo 1 (LFA-1) e molécula 1 de adesão intercelular (ICAM-1) na formação do contato célula-célula. Tax contribui para a formação de MTCO e o HTLV-1 integra o genoma do hospedeiro de forma clonal (idêntico em todas as células) e persistente.

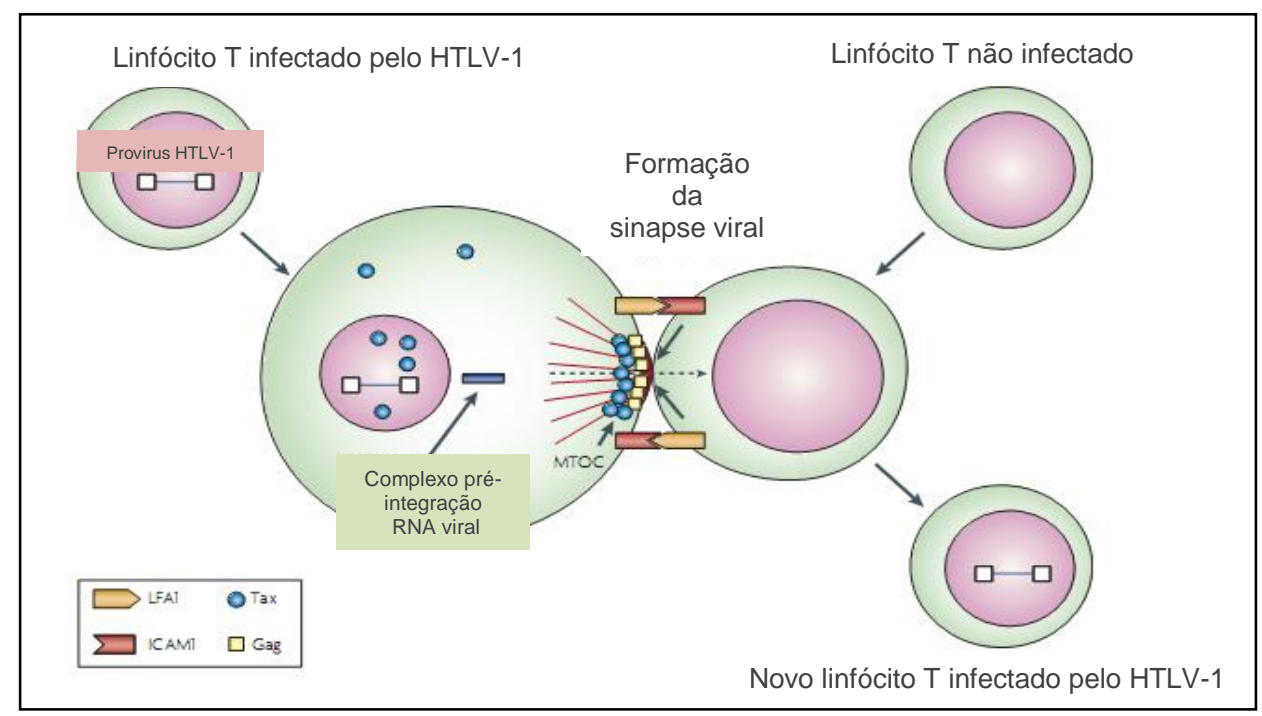

FONTE: Adaptado de Matsuoka; Jeang, 2007.

Figura 4 - Representação esquemática da sinapse viral

O HTLV-1 é um vírus pouco replicativo e acredita-se que o aumento da carga proviral in vivo ocorre, principalmente, devido à expansão policlonal das células infectadas, via mitose celular induzida pela ação de Tax e HBZ, em comparação à replicação viral via transcrição reversa (Nejmeddine; Bangham, 2010; Kress et al., 2011). A transmissão viral por meio da sinapse viral entre uma célula infectada e uma célula não infectada é $10^{4}$ vezes mais eficiente do que a do provírus (Nejmeddine; Bangham, 2010). 
Os diferentes desfechos clínicos apresentados pelos pacientes infectados pelo HTLV-1 dependem da interação entre o linfócito T CD4+ infectado e o linfócito T CD8+ do hospedeiro (Figura 5).

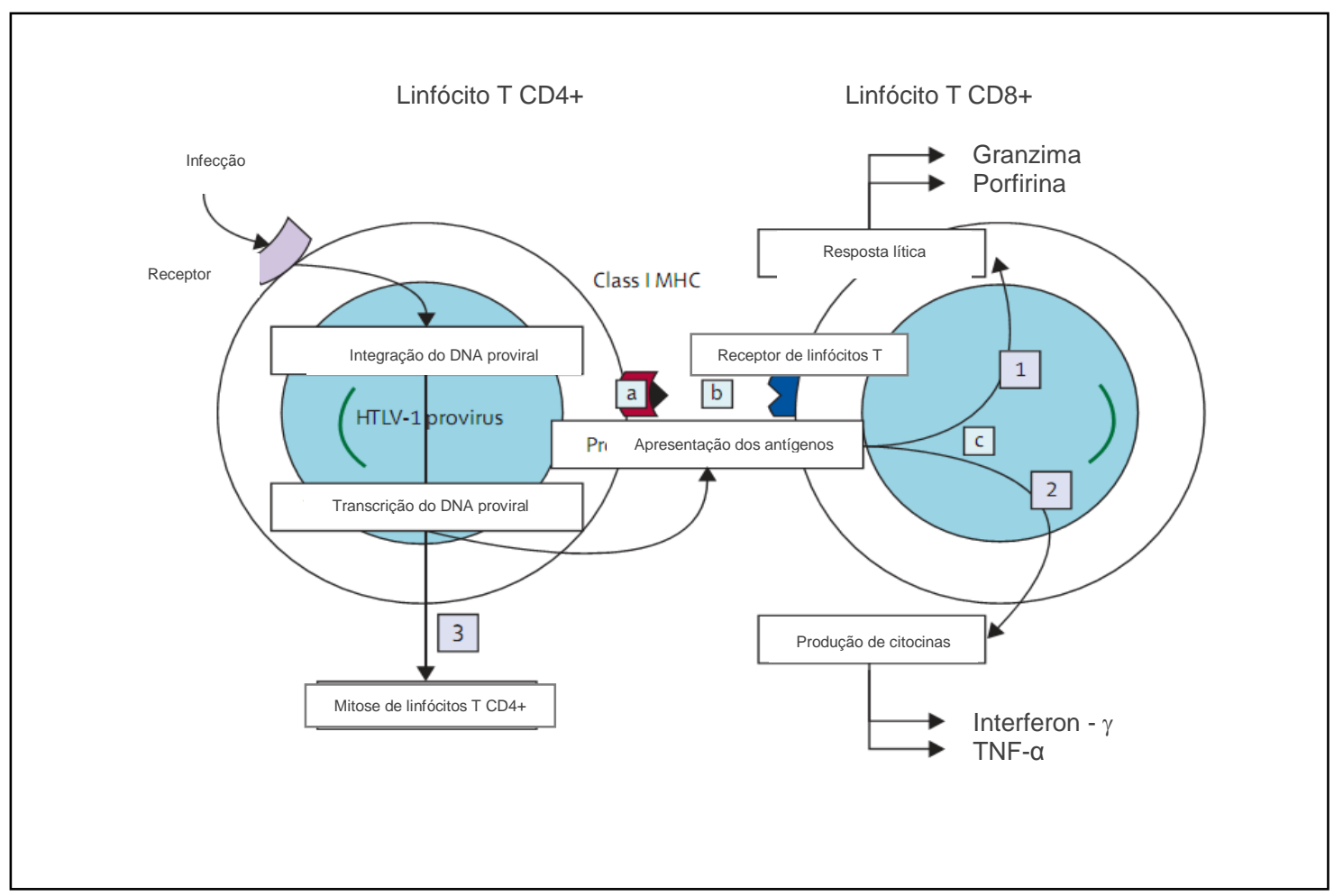

FONTE: Adaptado de Verdonck et al., 2007.

Figura 5 - A interação entre o linfócito T CD4+ infectado e o linfócito T CD8+ indica como a infecção pelo HTLV-1 pode conduzir a diferentes desfechos clínicos

Desfecho 1: uma resposta lítica eficiente controla a carga proviral e mantém assintomáticos os indivíduos infectados; desfecho 2: habitualmente, na presença de elevada carga proviral, a produção de citocinas inflamatórias naquele indivíduo pode conduzir ao desencadeamento de HAM/TSP, com o reconhecimento de linfócitos T CD4+ infectadas no SNC por linfócitos T CD8+ específicos ao HTLV-1; desfecho 3: a proliferação descontrolada de linfócitos T CD4+ infectadas pode conduzir ao desenvolvimento de ATLL. 
A relativa eficiência do desfecho 1 , quando comparada ao desfecho 2 , depende da: afinidade das diferentes moléculas de HLA com os peptídeos do HTLV-1 e a capacidade da porfirina de causar lise das células infectadas pelo HTLV-1 e o controle da carga proviral (a); interação com receptores dos linfócitos $\mathrm{T}$ (b); interação com hospedeiro em produzir mais fatores inflamatórios que líticos, com aumento da lesão neuronal, com recrutamento de linfócitos T CD4+ e linfócitos T CD8+ que aumentam o processo inflamatório e aumentam localmente a quantidade de células infectadas (c).

Particularmente na patogênese da HAM/TSP, acredita-se que sua desregulação do sistema imunológico desencadea uma resposta inflamatória crônica no sistema nervoso central, com dano neurológico. Fatores genéticos possivelmente estão envolvidos no processo de patogênese, tais como alguns haplótipos de HLA, grupos gênicos cuja recombinação de alelos pode conferir ao hospedeiro um perfil de susceptibilidade ou de proteção contra o desenvolvimento das mais diversas enfermidades (Casseb; Penalva-de-Oliveira, 2000). As três principais hipóteses que justificam o desenvolvimento da HAM/TSP são discutidas abaixo (Araujo; Silva, 2006; Martin; Taylor, 2011):

- Citotoxicidade Direta: as células gliais infectadas pelo HTLV-1 apresentam antígenos virais na sua superfície. CTLs específicos contra antígenos do HTLV-1 (principalmente contra a proteína Tax) atravessam a barreira hemato-encefálica e destroem as células infectadas por meio de atividade citotóxica direta ou pela 
liberação de citocinas pró-inflamatórias, como IFN-y e TNF $\alpha$ (Figura 6);

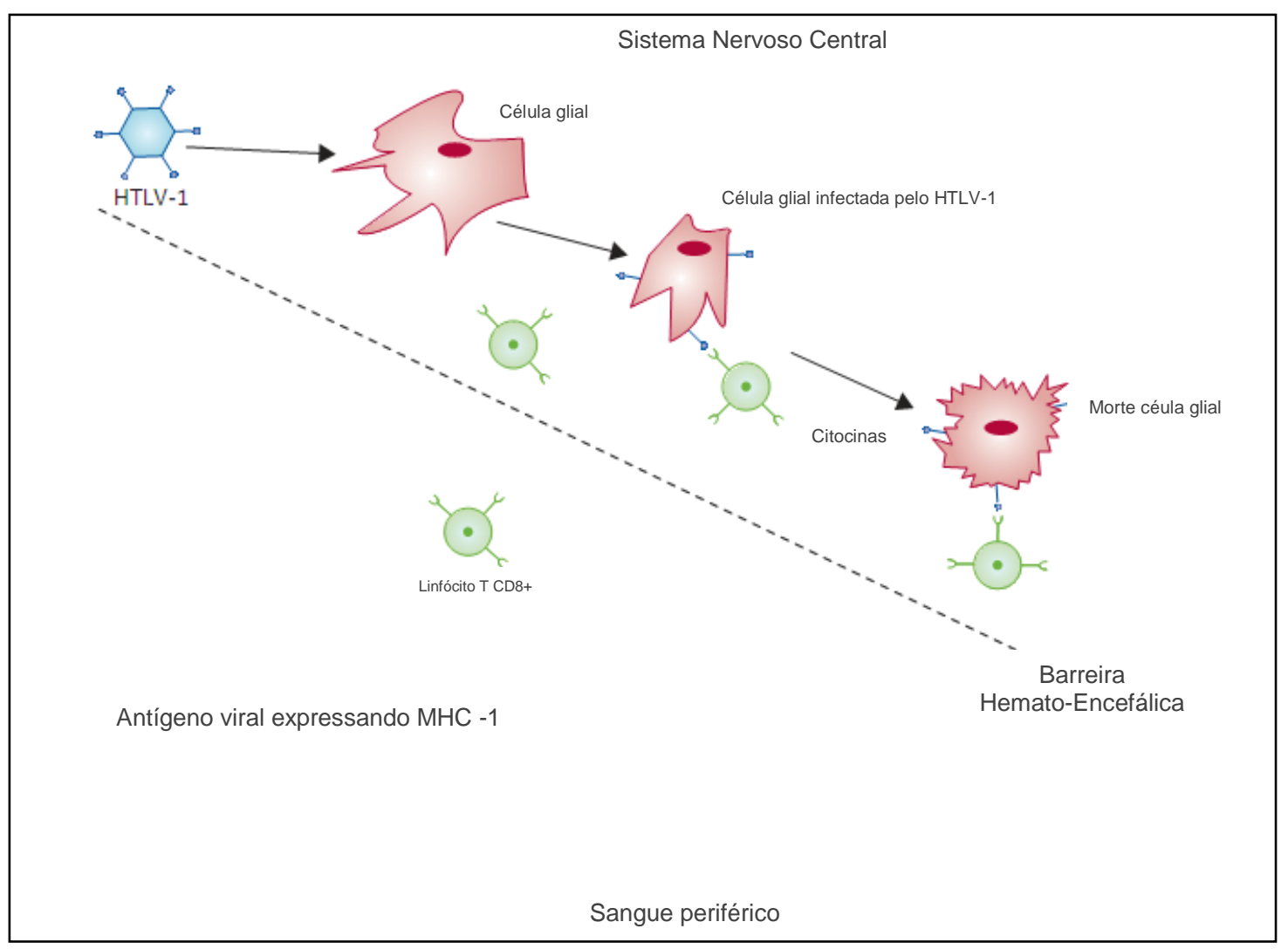

FONTE: Adaptado de Araujo; Silva, 2006.

Figura 6 - Hipótese da "Citotoxicidade Direta"

- Autoimunidade: as células gliais possuem, em sua superfície, antígenos símiles ao epítopos virais e, dessa forma, os linfócitos T CD4+ ativados atravessam a barreira hemato-encefálica, confundem as células gliais normais com as infectadas pelo HTLV1 e reagem contra essas células, desencadeando uma resposta inflamatória que resulta na morte tanto das células gliais normais como das infectadas (Figura 7). A proteína neuronal, ribonucleoproteína nuclear heterogênea (hnRNP-A1), e o 
autoantígeno da mielina apresentam reatividade cruzada com anticorpos anti-Tax e são exemplos desse mimetismo molecular de autoantígeno;

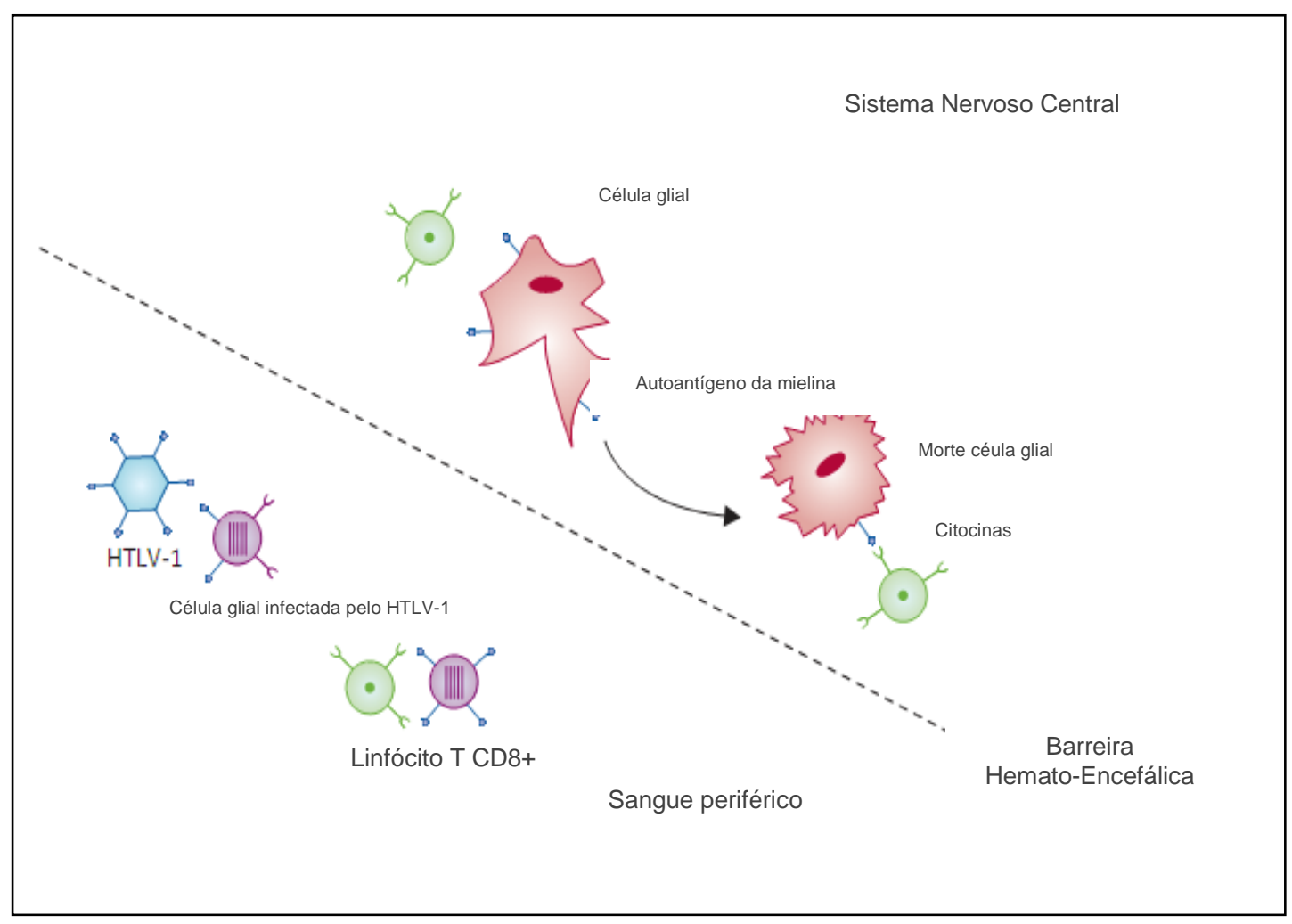

FONTE: Adaptado de Araujo; Silva, 2006.

Figura 7 - Hipótese da "Autoimunidade"

- Dano Colateral: CTLs específicos contra antígenos do HTLV-1 e linfócitos T CD4+ infectados pelo HTLV-1 atravessam a barreira hemato-encefálica e produzem uma resposta inflamatória, liberando citocinas que destroem as células gliais (Figura 8). 


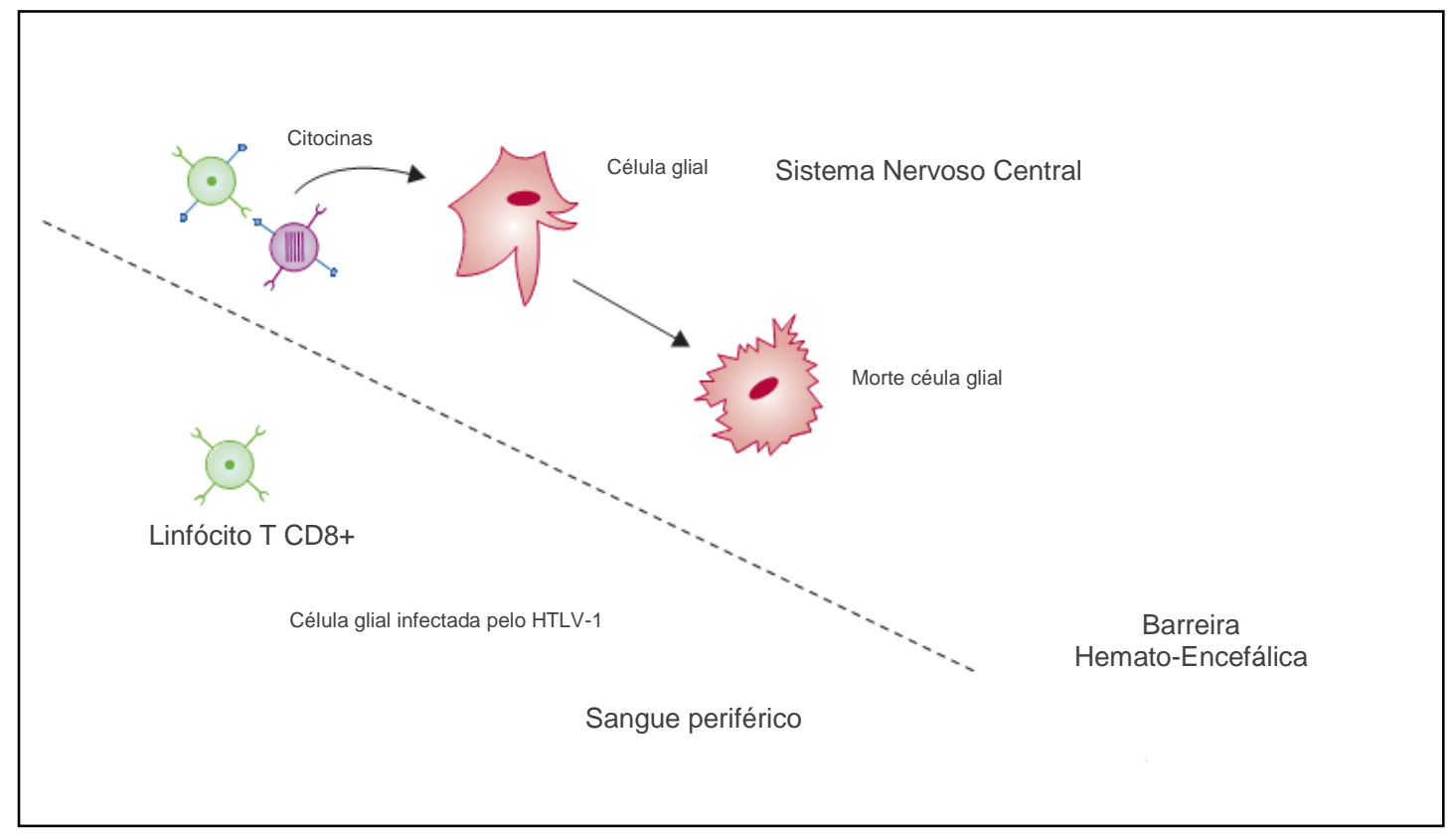

FONTE: Adaptado de Araujo; Silva, 2006.

Figura 8 - Hipótese do "Dano Colateral"

A inflamação que se observa na infecção do SNC por HTLV-1 é mais intensa na medula torácica, provavelmente pelo baixo fluxo sanguíneo e, consequentemente, maior concentração de moléculas de adesão e migração para o sistema nervoso central. Os achados histopatológicos nessa condição revelam infiltrado linfocítico perivascular com linfócitos T CD4+ e linfócitos T CD8+ nas lesões iniciais, e predomínio de linfócitos T CD8+ nas lesões tardias, evoluindo para atrofia medular, e degeneração axonal e de mielina (Martin; Taylor, 2011). 


\subsection{Manifestações clínicas}

A maioria dos indivíduos infectados pelo HTLV-1 permanecerá assintomática ao longo da sua vida; entretanto, $2 \%$ a $5 \%$, evoluirá com quadro de HAM/TSP e $1 \%$ a $3 \%$ com leucemia/linfoma de células $\mathrm{T}$ do adulto (ATLL). Outras doenças também associadas ao HTLV-1 já foram descritas, tais como uveítes, dermatite infecciosa, infecção urinária de repetição, síndrome de Sjögren, tireoidite, artropatia, poliomiosite, polineuropatia e alveolite. A infecção por esse retrovírus humano é ainda considerada fator de risco para o desenvolvimento de outras infecções, tais como a causada por Strongyloides stercoralis, escabiose, hanseníase e tuberculose (Marinho et al., 2005; Verdonck et al., 2007). Dados os objetivos desta dissertação, apresentam-se, a seguir, de modo detalhado, as características clínicas da doença neurológica causada por HTLV-1.

\subsubsection{Quadro clínico da HAM/TSP}

A HAM/TSP é a manifestação neurológica mais descrita da infecção por esse retrovírus e é uma doença neurodegenerativa, com acometimento da substância cinzenta e branca na medula espinhal, caracterizada por desmielinização e degeneração axonal. É lentamente progressiva e 
determina, principalmente, paraparesia espástica tropical, bexiga neurogênica, constipação intestinal, hiper-reflexia dos membros inferiores, associadas ou não a outras manifestações neurológicas e não neurológicas. O pico de incidência da doença é, geralmente, na terceira ou quarta década de vida (Araujo; Silva, 2006).

No "Report from the Scientific Group on HTLV-I Infection and its Associated Diseases, convened by the Regional Office for the Western Pacific of the World Health Organization in Kagoshima" (1989), organizado pela OMS, foram definidos critérios diagnósticos de HAM/TSP, com base em dados clínicos e laboratoriais (Quadro 1).

Quadro 1 - Critérios clínicos e laboratoriais da OMS para definição HAM/TSP I. Critérios clínicos

O quadro de paraparesia espástica crônica não é sempre visto inicialmente. Um sintoma ou sinal clínico único pode ser a única evidência de HAM/TSP incipiente.

A. Idade e sexo: a maioria dos casos esporádicos ocorre em adultos, mas, às vezes, há mais de um caso na mesma família; ocasionalmente em crianças; predomínio em mulheres.

B. Início: geralmente insidioso, mas pode ser agudo.

C. Principais manifestações neurológicas:

- Paraparesia espástica crônica, de progressão lenta e que permanece estática após uma progressão inicial;

- $\quad$ Fraqueza dos membros inferiores, de predomínio proximal;

- Distúrbio vesical é uma característica inicial; constipação geralmente ocorre mais tarde; impotência sexual e libido diminuída são comuns;

- Sintomas sensitivos, tais como formigamento ou queimação são mais proeminentes que os sinais físicos objetivos;

- Dor lombar baixa com irradiação para as pernas é comum;

- A sensibilidade vibratória está frequentemente alterada; a propriocepção é menos afetada;

- Hiper-reflexia dos membros inferiores, frequentemente com clônus e sinal de Babinski;

- Hiper-reflexia dos membros superiores; sinais de Hoffmann e Trömner são frequentes; fraqueza pode estar ausente;

- Reflexo mandibular exagerado em alguns pacientes. 
conclusão

\begin{tabular}{|c|c|}
\hline D. & $\begin{array}{l}\text { Achados neurológicos menos frequentes: } \\
\text { - } \quad \text { Sinais cerebelares, atrofia óptica, surdez, nistagmo, deficiências em } \\
\text { outros nervos cranianos, tremor dos dedos e mãos e hipo ou arreflexia } \\
\text { aquiliana; } \\
\text { - Convulsões, distúrbio cognitivo, demência ou distúrbio da consciência } \\
\text { são raros. }\end{array}$ \\
\hline E. & $\begin{array}{l}\text { Manifestações neurológicas que podem estar associadas: } \\
\text { - Atrofia muscular, fasciculações (raras), polimiosite, neuropatia } \\
\text { periférica, polirradiculopatia, neuropatia de nervos cranianos, } \\
\text { meningite e/ou encefalopatia. }\end{array}$ \\
\hline $\mathrm{F}$. & $\begin{array}{l}\text { Manifestações sistêmicas associadas à HAM/TSP: } \\
\text { - Alveolite linfocitária pulmonar, uveíte, síndrome de Sjögren, artropatia, } \\
\text { vasculite, ictiose, crioglobulinemia, gamopatia monoclonal e/ou } \\
\text { leucemia/linfoma de célula T do adulto. }\end{array}$ \\
\hline \multicolumn{2}{|c|}{ II. Diagnóstico laboratorial } \\
\hline A. & $\begin{array}{l}\text { Presença de anticorpos anti-HTLV-1 no sangue e no líquido } \\
\text { cefalorraquidiano (LCR); }\end{array}$ \\
\hline B. & O LCR pode mostrar discreta pleocitose linfocítica; \\
\hline C. & Linfócitos lobulados podem estar presentes no sangue e/ou LCR; \\
\hline D. & Pode haver discreta a moderada hiperproteinorraquia; \\
\hline E. & Quando possível, isolamento viral no sangue e/ou LCR. \\
\hline
\end{tabular}
FONTE: OMS, 1989

Entretanto, 21,5\% dos pacientes com HAM/TSP podem evoluir com uma incapacidade neurológica progressiva nos primeiros dois anos da infecção, a partir do início dos primeiros sinais e sintomas, sendo mais relatada em indivíduos mais jovens, que adquiriram a infecção por via sanguínea, com alta carga proviral plasmática e altos títulos de anticorpos, e em pacientes imunossuprimidos por transplante de órgãos sólidos. Isso pode acontecer pela fase degenerativa prolongada após a fase inflamatória inicial, com maior proliferação e migração de linfócitos infectados pelo HTLV-1 no sistema nervoso central (Nagai et al., 1998; Araujo; Silva, 2006). 
É mais comum em mulheres (três mulheres para um homem) e antes da menopausa. Tais diferenças de gênero na incidência de HAM/TSP podem ser atribuídas aos hormônios sexuais femininos. É menos comum nos pacientes com HLA-A02 ou HLA-Cw08 que apresentam menores cargas provirais, e isso pode ser atribuído à atividade mais eficiente de CTLs específicos contra antígenos de HTLV-1 (Vine et al., 2002; Martin; Taylor, 2011).

Fraqueza nos membros inferiores é o primeiro sintoma a ser percebido em, aproximadamente, $60 \%$ dos pacientes, com evolução progressiva para uma marcha espástica. Entretanto, nem todos necessitarão de cadeiras de rodas. Durante a evolução, a disfunção vesical é comum, com incontinência ou retenção urinária, urgência miccional e polaciúria. A combinação de distúrbios urinários irritativos e obstrutivos é comum, e pode anteceder o quadro de paraparesia em muitos anos. O estudo urodinâmico revela bexiga hiperreativa e dissinergia do esfíncter do detrusor.

Outros sinais e sintomas comuns são a constipação intestinal, lombalgia e parestesia em membros inferiores. No exame neurológico, os pacientes apresentam marcha espástica com fraqueza nos membros inferiores, hiper-reflexia (alguns apresentam-na também em membros superiores) e sinal de Babinski.

A força nos membros superiores é, habitualmente, preservada, mas os reflexos profundos podem apresentar-se exaltados. Sinal de Hoffmann e reflexo mentoniano exaltado podem estar presentes. 
A marcha espástica e a disfunção esfincteriana são os sinais e sintomas mais incapacitantes para os pacientes (Araujo; Silva, 2006).

O quadro de HAM/TSP pode estar associado também com alveolite pulmonar, uveíte, artrite, dermatite, síndrome Sjögren, doença de Behçet, doenças da tireoide, cistites de repetição e prostatites (Verdonck et al., 2007).

A coexistência de HAM/TSP e ATLL no mesmo paciente, apesar de relatada, permanece incomum.

Como a doença geralmente manifesta-se, clinicamente, a partir da quarta década de vida, outras doenças degenerativas dificultam 0 diagnóstico da mielopatia do HTLV-1 ao se apresentarem com sinais e sintomas semelhantes, como espondilodiscopatias degenerativas.

Araujo e Silva (2006) propuseram uma nova nomenclatura, complexo neurológico do HTLV-1, para contemplar todas as manifestações neurológicas associadas à infecção por esse retrovírus, particularmente entre pacientes oligoassintomáticos que não apresentam todos os critérios para o diagnóstico de HAM/TSP (a parte mais visível do iceberg que representa o complexo neurológico do HTLV-1) e, provavelmente, a minoria dos pacientes atendidos (Figura 9). 


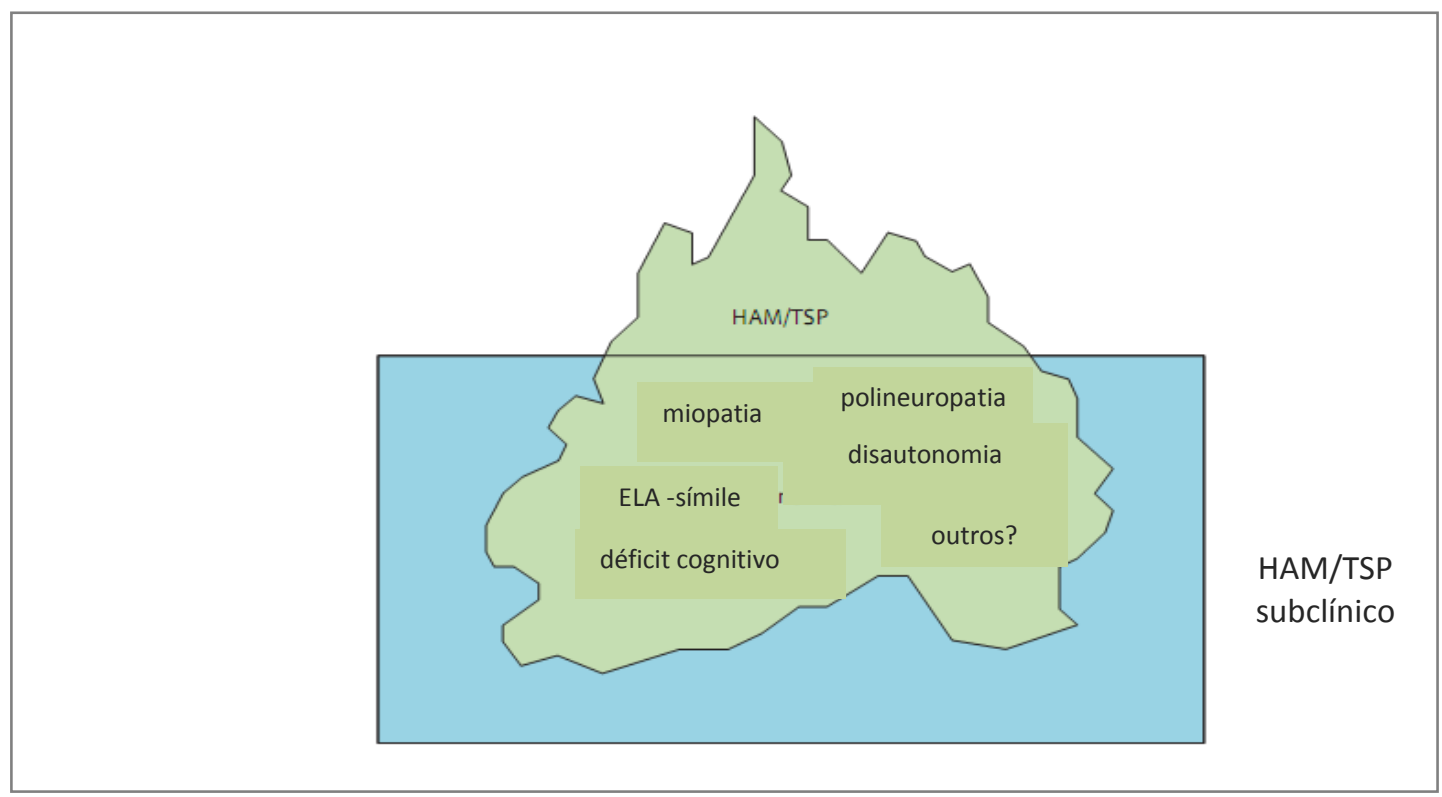

FONTE: Adaptado de Araujo; Silva, 2006.

Figura 9 - Representação esquemática do complexo neurológico do HTLV-1

O complexo neurológico inclui, também, as miopatias, polineuropatias, síndrome da esclerose lateral amiotrófica-símile (ELA-símile), déficits cognitivos, disautonomias, uveítes, encefalomielites e ataxias. Talvez esses pacientes sejam mais beneficiados com as novas propostas terapêuticas, se aplicadas precocemente, quando comparados aos com HAM/TSP.

Diagnóstico diferencial deve ser realizado com esclerose múltipla, mielopatia vacuolar da Aids, paraparesia espática familiar, esclerose lateral primária, compressão da medula espinhal, deficiência de vitamina B12, neuroesquistossomose, neurolatirismo, doença de Lyme e neurossífilis (Araujo; Silva, 2006). 


\subsection{Diagnóstico}

O diagnóstico de HAM/TSP consiste na avaliação epidemiológica, clínica (descrita acima) e laboratorial do paciente. $\mathrm{Na}$ avaliação epidemiológica, deve-se indagar sobre a ascendência da família, naturalidade, procedência, presença de familiares portadores do HTLV, profissão e antecedentes de aleitamento materno, hemotransfusão, cirurgia, uso de droga intravenosa, atividade sexual, acupuntura, tatuagem, piercing e acidente com material biológico.

A avaliação laboratorial consiste na demonstração da infecção por meio da pesquisa de anticorpos anti-HTLV-1/2 nos fluidos orgânicos, principalmente no soro e LCR.

Os métodos sorológicos podem ser classificados em reações de triagem e de confirmação. Os de triagem baseiam-se na detecção sorológica de anticorpos específicos para componentes antigênicos das diferentes porções do vírus (core e envelope), como a aglutinação de partículas ou os testes imunoenzimáticos (ELISA) que utilizam como antígeno o lisado viral, frações recombinantes ou peptídeos sintéticos. Entretanto, esses podem apresentar resultados falso-positivos, fazendo-se necessária a confirmação do resultado por ensaios com alta especificidade e capazes de distinguir a infecção causada pelo HTLV-1 daquela causada pelo HTLV-2. Para tal, empregam-se os testes de Western blot (WB), imunoblot, 
imunofluorescência ou métodos de detecção molecular, principalmente a reação em cadeia por polimerase (PCR) (Costa et al., 2011).

O Ministério da Saúde (MS) recomenda que as amostras definidas por WB como "positivas não tipadas", "positivas para HTLV-1/2" e "indeterminadas para HTLV" sejam submetidas a técnicas de biologia molecular, tais como a PCR e a análise de polimorfismo do comprimento dos fragmentos de restrição (RFLP) para confirmação do diagnóstico e para diferenciar a infecção pelo HTLV-1 daquela causada pelo HTLV-2 (BRASIL, 2003; Abrams et al., 2011).

A diferença na sororreatividade a epítopos tipo-específicos derivados da gp46 ao WB permite distinguir o tipo viral causador da infecção (Feuer; Green, 2005).

Linfócitos atípicos em sangue periférico, hipergamaglobulinemia, aumento de beta-2-microglobulina e aumento do número de linfócitos CD4+ são anormalidades laboratoriais que podem ser encontradas nesses pacientes.

Durante os primeiros anos da evolução da doença, há pleocitose moderada e aumento da concentração de proteínas no LCR, que tendem a declinar gradualmente. Há, também, bandas oligoclonais, aumento de citocinas, como neopterina, TNF a, IL-6 e aumento da síntese de anticorpo intratecal específico para HTLV-1. Alguns pacientes com HAM/TSP também apresentam a razão da carga proviral do LCR com a do sangue periférico superior a $10 \%$, enquanto nos portadores assintomáticos esta é inferior a 10\% (Araujo; Silva, 2006). 
Entre os métodos de imagem, a ressonância nuclear magnética destaca-se na investigação de lesões na substância branca e deteç̧ão de sinais de mielopatia, podendo indicar inflamação em atividade. Esse método também facilita o diagnóstico diferencial com outras afecções (eg, fraturas, hérnia de disco, neoplasias, mielorradiculopatia da esquistossomose) (Ribas; Melo, 2002).

\subsection{Tratamento}

Até o momento, não há evidências de qualquer intervenção terapêutica que propicie a cura da HAM/TSP, nem tampouco existe a evidência do benefício terapêutico com qualquer intervenção frente à ausência de estudos conclusivos a respeito. Muitos tratamentos tentaram diminuir e/ou bloquear o processo inflamatório e, consequentemente, evitar a piora do quadro de HAM/TSP.

Os medicamentos mais utilizados, como os relaxantes musculares, antiespasmódicos urinários e analgésicos, por exemplo, visam ao alívio dos sinais e sintomas de espasticidade, constipação intestinal, bexiga neurogênica e dores (Araujo; Silva, 2006); os glicocorticoides, interferons, antirretrovirais análogos de nucleosídeos (zidovudina e lamivudina), gamaglobulina e outros foram muito utilizados na década de 1990 e início deste século, e visam à modulação da resposta imune na tentativa de 
diminuir a progressão dos sinais e sintomas mais comuns (Duncan; Rudge, 1990; Kuroda et al., 1992; Izumo et al., 1996; Nakagawa et al., 1996; Shirabe et al., 1997; Taylor et al., 2006; Arimura et al., 2007; Oh; Jacobson, 2008; Carod-Artal, 2009).

Cartier et al. (1996) descreveram um estudo aberto que avaliou o uso de citidina monofosfato, uridina trifosfato e vitamina B12 no tratamento de pacientes adultos com HAM/TSP, comparando-o com placebo, com melhora temporária do quadro clínico e sem eventos adversos observados.

Martin e Taylor (2011) enfatizaram as dificuldades para descobrir novos tratamentos para $\mathrm{HAM} / \mathrm{TSP}$, que incluem o fato da maior parte dos pacientes acometidos provirem de países em desenvolvimento, nos quais o acesso a serviços de saúde é precário e a obtenção de dados é realizada de forma incompleta; o longo período de latência e a evolução insidiosa da doença, que dificultam a realização de estudos clínicos; o fato dos pacientes apresentarem-se aos serviços de saúde em diferentes estágios da doença; o entendimento ainda limitado do conhecimento neurológico e o elevado custo dos estudos, que não são financiados pelo setor público.

Além disso, deve-se destacar que não há biomarcadores disponíveis no momento para serem utilizados como ferramentas para predizer a melhora ou piora do quadro clínico durante o acompanhamento. Esse ainda se faz com base na avaliação prospectiva do exame físico, e nos sinais e sintomas referidos pelo paciente.

Acredita-se que a melhor abordagem terapêutica para esses pacientes seja a multidisciplinar (Fisiatria, Psicologia, Psiquiatria, Fisioterapia, Nutrição, 
Terapia Ocupacional, Assistência Social, Ortopedia, Reumatologia, Oftalmologia, Urologia e Infectologia), visando diminuir a incapacidade e melhorar a qualidade de vida dos pacientes acometidos.

Com os avanços na elucidação dos mecanismos patogênicos desencadeados pelo HTLV-1, os medicamentos imunomoduladores parecem ser a mais efetiva intervenção farmacológica em HAM/TSP.

Medicamentos imunomoduladores são fármacos utilizados para modular a resposta imune por três mecanismos: imunossupressão, tolerância e imunoestimulação, com modificação do perfil das citocinas próinflamatórias para anti-inflamatórias (Bennett et al., 2010).

No ambulatório de HTLV, do Instituto de Infectologia Emílio Ribas, foi descrita uma coorte prospectiva de junho de 1997 a junho de 2006, contendo 39 pacientes com HAM/TSP que receberam um grama de metilprednisolona intravenoso por dia, durante três dias consecutivos, a cada três ou quatro meses, acompanhados durante dois anos e dois meses. Esses pacientes receberam uma média de 3,4 pulsos associados aos medicamentos antiespamódicos e fisioterapia, e 24,5\% apresentaram melhora do quadro neurológico na escala ISS (Incapacity Status Scale). As propriedades anti-inflamatórias dos corticosteroides podem ter algum impacto no dano causado à mielina, com melhora temporária em alguns sinais e sintomas, principalmente em pacientes com quadro inicial de HAM/TSP (Croda et al., 2008). 


\subsection{Medidas para prevenção}

A infecção pelo HTLV-1, na grande maioria dos casos, não determina qualquer alteração clínica, permitindo aos portadores infectados passar a vida toda sem conhecer seu diagnóstico ou serem diagnosticados eventualmente, pela triagem sorológica para doação de sangue.

Magnus et al. (1996) realizaram um estudo cujo objetivo foi avaliar custo-efetividade da testagem rotineira de doadores de sangue, baseandose na prevalência estimada de infecção pelo HTLV. O estudo usou Quality Adjusted Life Years (QALYs) no planejamento de medidas de prevenção, considerando uma probabilidade de $20 \%$ de soroconversão após o recebimento de transfusão de sangue proveniente de doadores portadores de HTLV assintomáticos, $1 \%$ de probabilidade de desenvolver HAM/TSP com uma fase latente de 10 anos e duração média de 20 anos, e $5 \%$ de desenvolver ATLL com uma fase latente de 25 anos e duração média de um ano.

O QALYs é um indicador que integra mortalidade e morbidade, e expressa o estado de saúde em termos de anos de vida. Uma unidade dessa medida, ou 1 QALY, é definido como o equivalente a um ano de vida vivido na plenitude de bem-estar, ou seja, completamente livre de sintomas, problemas ou condições que possam afetar o bem-estar. A conclusão desse estudo de custo-efetividade considera o benefício da implementação da 
testagem se a prevalência de infecção na população geral for de 20 portadores de HTLV por 100.000 pessoas.

Desde a aprovação da Portaria n 1.376, de 19/11/1993, e da Portaria № 2.600, de 21/09/2009, a testagem sorológica para HTLV -1 e HTLV-2 é obrigatória em nosso país para os candidatos a doador de sangue e hemocomponentes, e para doadores ou receptores de órgãos, tecidos, células ou partes do corpo humano, respectivamente.

$\mathrm{Na}$ tentativa de diminuir a disseminação do HTLV, algumas medidas de prevenção são recomendadas (Recommendations for counseling persons infected with human T-Iymphotrophic virus, types I and II. MMWR Recomm Rep. 1993; Catalan-Soares et al., 2005):

1. Na orientação de indivíduos soropositivos para HTLV, recomendase:

- Não doar sangue, sêmen ou órgãos;

- Não compartilhar agulhas ou seringas;

- Não amamentar, se possível;

- Usar preservativo nas relações sexuais, de acordo com a decisão do casal.

2. Para identificação de novos casos, oferecer a testagem para aqueles que se enquadrem em um ou mais dos critérios abaixo:

- $\quad$ Filhos de mulheres soropositivas para HTLV (quer tenham sido amamentados ou não); 
- Indivíduos que receberam transfusão de sangue e hemocomponentes antes de 1993 (ou que tenham parceiros sexuais nessa situação);

- Usuários ou ex-usuários de drogas intravenosas (ou que tenham parceiros sexuais nessa situação);

- Pacientes portadores de HIV com manifestações neurológicas sugestivas e/ou quando apresentam número elevado de células CD4+ periféricas e discrepante do quadro clínico e dos dados laboratoriais apresentados;

- Indivíduos que identifiquem na família casos de leucemia/linfoma de células $\mathrm{T}$ do adulto, mielite não traumática e/ou uveíte intermediária.

3. Na implementação de medidas de saúde pública (além dos testes de triagem em bancos de sangue) recomenda-se:

- Controle de bancos de leite por meio de oferecimento de teste de triagem de candidatas à doação, excluindo as soropositivas para HTLV;

- Teste de gestantes no pré-natal com intuito de identificar e aconselhar as mães soropositivas a não amamentar os bebês, e possibilitar aleitamento artificial para esses. 


\subsection{Medicina Baseada em Evidências}

A revisão narrativa está sendo substituída pela revisão sistemática, um método de investigação científica com planejamento e reunião de estudos originais, reprodutível e que sintetiza os resultados de múltiplas investigações primárias por meio de estratégias que limitam viéses e erros aleatórios. Além disso, aumenta a acurácia dos resultados e fornece com mais precisão a estimativa da eficácia de uma intervenção do que um estudo sozinho (Cook et al., 1997). Essa mudança é a prática clínica baseada em evidências, lançada, em 1992, com o nome de Evidence-Based Medicine (Evidence-Based Medicine Working Group, 1992).

Para a decisão do melhor tratamento em qualquer doença, os ensaios clínicos randomizados e controlados (ECRs) são considerados os mais adequados, principalmente quando é possível a realização de metanálise, para avaliação mais precisa dos resultados, aumentando ainda mais a força de evidência, porque produz uma única medida do efeito do tratamento avaliado ao combinar os dados dos trabalhos para aumentar o tamanho da população analisada e reduzir o intervalo de confiança (Castro et al., 2002; Bernardo et al., 2004).

Com o aumento da demanda de pacientes portadores de HTLV-1 à procura de atendimento médico e com a escassez de recursos aplicados em projetos para tratamento e/ou cura, a revisão sistemática pode ajudar a decidir qual é a melhor intervenção terapêutica no tratamento de HAM/TSP, 
e, também, a chamar atenção para a necessidade de melhorar a prevenção

e o acesso à informação sobre o vírus e suas repercussões, principalmente no nosso país.

Entretanto, pode ser difícil compilar inúmeras informações geradas de estudos com pacientes heterogêneos, vieses, falhas metodológicas e dependentes do contexto e tempo, conduzindo a conclusões conflituosas. No processo de identificação de estudos, é possível encontrar estudos publicados mais de uma vez e estudos publicados em revistas não indexadas ou não publicados, dificultando o acesso às informações (Castro et al., 2002).

Até o momento, não há nenhuma revisão sistemática sobre a eficácia de qualquer intervenção farmacológica imunomoduladora em HAM/TSP e não existe ainda nenhum tratamento curativo disponível. Portanto, os tratamentos atualmente utilizados têm um custo social e financeiro oneroso para o paciente, sua família e para o sistema de saúde.

\subsection{Justificativa do estudo}

A finalidade deste trabalho é rever e sintetizar as evidências clínicas existentes sobre a eficácia dos medicamentos imunomoduladores utilizados no tratamento de pacientes adultos com HAM/TSP para permitir a melhor tomada de decisão clínica, e auxiliar em futuras pesquisas e orientações. 
2 Objetivos 


\section{OBJETIVOS}

Realizar uma revisão sistemática de ECRs, com metanálise, se possível, sobre a eficácia dos medicamentos imunomoduladores utilizados no tratamento da HAM/TSP em pacientes adultos.

\subsection{Hipótese}

As hipóteses a serem testadas são:

$$
\begin{aligned}
& \mathrm{H}_{0}=\text { imunomoduladores }=\text { placebo } \\
& \mathrm{H}_{1}=\text { imunomoduladores }>\text { placebo } \\
& \mathrm{e} \\
& \mathrm{H}_{0}=\text { imunomodulador } \mathrm{x}=\text { imunomodulador } \mathrm{y} \\
& \mathrm{H}_{1}=\text { imunomodulador } \mathrm{x}>\text { imunomodulador } \mathrm{y}
\end{aligned}
$$




\subsection{Pergunta}

Qual dos medicamentos imunomoduladores apresenta melhor resultado clínico no tratamento de pacientes adultos com HAM/TSP?

\subsection{Objetivos específicos}

- Identificar ECRs de tratamento de pacientes adultos com HAM/TSP;

- Verificar a qualidade metodológica desses ECRs;

- Avaliar a eficácia dos imunomoduladores, comparando-a com a de placebo e entre eles, em relação à melhora da função motora, do distúrbio urinário e melhora da dor em membros inferiores;

- Avaliar os efeitos adversos dos imunomoduladores. 


\section{MÉtodos}




\section{MÉTODOS}

Uma busca preliminar foi realizada para verificar a existência de alguma revisão sistemática sobre a questão selecionada e não foi encontrada nenhuma nas seguintes fontes:

- Banco de dados de revisões sistemáticas da Cochrane (Cochrane Database of Systematic Reviews). Acesso disponível pelo http://www.cochrane.org/cochrane-reviews e realizado no dia 31/01/13;

- Banco de dados acessados por meio do site do Centro de Revisões e Disseminação da Universidade de York e do Instituto Nacional de Pesquisa em Saúde do Reino Unido (National Institute for Health Research - NIHR). Acesso disponível pelo http://www.york.ac.uk/inst/crd/ e realizado no dia $31 / 01 / 2013$.

O método dessa pesquisa seguiu as recomendações para a realização de revisões sistemáticas propostas pela Associação Médica Brasileira Projetos Diretrizes (Nobre et al., 2003). 


\subsection{Tipo de estudo}

Revisão sistemática de ensaios clínicos randomizados e controlados sobre a eficácia dos medicamentos imunomoduladores no tratamento da HAM/TSP.

Outros tipos de artigos obtidos pelos métodos de identificação de estudos, como estudos abertos, séries ou relatos de casos, embora não incluídos na revisão sistemática, foram descritos como parte da revisão de literatura.

\subsection{Local}

A presente investigação foi desenvolvida no Departamento de

Moléstias Infecciosas e Parasitárias da Faculdade de Medicina da Universidade de São Paulo. 


\subsection{Tipos de participantes envolvidos nos estudos}

Indivíduos de ambos os sexos, com idade acima de 18 anos e com diagnóstico de HAM/TSP firmado com base nos critérios estabelecidos no consenso da OMS de 1989.

\subsection{Tipos de intervenções}

Comparação dos seguintes imunomoduladores contra placebo e entre eles mesmos:

- $\quad$ Glicocorticoides;

- $\quad$ Ciclosporina;

- Azatioprina;

- Daclizumabe;

- Interferons;

- Gamaglobulina;

- Antirretrovirais;

- Imunoglobulinas;

- Pentoxifilina;

- $\quad$ Anticorpos monoclonais; 
- Sulfassalazina;

- Danazol;

- Mizoribina.

3.5 Tipos de desfechos avaliados

\subsubsection{Desfechos primários}

- $\quad$ Melhora da dor em membros inferiores;

- Melhora da marcha;

- Melhora do distúrbio urinário.

\subsubsection{Desfechos secundários}

- $\quad$ Adesão ao tratamento;

- $\quad$ Efeitos adversos. 


\subsection{Estratégia de busca para identificação dos estudos}

A questão da pesquisa deve ser específica, de relevância científica e formulada de modo sistemático. A obtenção de estudos que respondem a uma questão clínica faz parte do entendimento que procura integrar a melhor evidência científica às necessidades do paciente. O processo de encontrar a resposta apropriada à questão clínica surgida no atendimento depende da forma como estruturamos as partes deste processo. A forma preconizada é conhecida pelo acrônimo PICO formada por P de paciente ou população, I de intervenção ou indicador, $\mathrm{C}$ de comparação ou controle e $\mathrm{O}$ de outcome (desfecho clínico), resultado ou a resposta que se espera encontrar nas fontes de informação científica (Nobre et al., 2003).

Utilizamos a forma estruturada sintetizada pelo acrônimo EPICOT, que deriva da estratégia PICO (Robinson et al., 2011), em que:

- $\quad$ E: Evidência atual (ECRs);

- P: Paciente em questão ou população estudada (ambos os sexos, com idade acima de 18 anos de idade e com HAM/TSP pelo HTLV-1);

- I: Intervenção, exposição, teste ou indicador a ser testado (imunomoduladores);

- C: Comparação ou grupo-controle (placebo e entre os imunomoduladores); 
- O: "Outcome", resultado ou desfecho esperado (melhora dos sintomas);

- T: Tempo ou data da recomendação (atualizado no dia $31 / 1 / 2013)$.

\subsubsection{Base de dados bibliográficos}

A pesquisa foi realizada nas seguintes bases de dados bibliográficos, sem restrição de idioma em busca de estudos publicados até 31/01/13:

- MEDLINE (Medical Literature Analysis and Retrieval System Online) é uma base de dados produzida pela National Library of Medicine (NLM), nos Estados Unidos, com referências bibliográficas e resumos de mais de 5.000 títulos de revistas publicadas nos Estados Unidos e em outros 70 países. Contém referências de artigos publicados desde 1966, que cobrem as áreas de: Medicina, Biomedicina, Enfermagem, Odontologia, Veterinária e Ciências afins. A atualização da base de dados é mensal (BVS, 2012);

- $\quad$ LILACS (Literatura Latino-Americana e do Caribe em Ciências da Saúde) é um indexador bibliográfico da literatura relativa às Ciências da Saúde, publicada nos países da América Latina e 
Caribe, a partir de 1982. É um produto cooperativo da Rede da Biblioteca Virtual em Saúde (BVS) e, em 2009, atingiu 500.000 mil registros bibliográficos de artigos publicados em cerca de 1.500 periódicos em Ciência da Saúde, dos quais, aproximadamente, 800 são, atualmente, indexados. A LILACS também indexa outros tipos de literatura científica e técnica, tais como teses, monografias, livros e capítulos de livros, trabalhos apresentados em congressos ou conferências, relatórios, publicações governamentais e de organismos internacionais regionais. Pode ser acessado para pesquisa bibliográfica no Portal Global da BVS e os registros são também indexados no Google (BVS, 2012);

- Embase (Excerpta Medica Database) é uma base de dados que reúne periódicos mundiais sobre biomedicina e é produzida desde 1974 pela Elsevier, uma entidade dedicada à edição de publicações científicas e técnicas, serviços e informações, sob a forma de livros, revistas, portais e bases de dados, disponibilizadas a autores, editores, livreiros, cientistas e outros (BVS, 2012);

- Biblioteca Cochrane consiste em uma coleção de fontes de informação atualizada sobre Medicina Baseada em Evidências, incluindo a Base de Dados Cochrane de Revisões Sistemáticas que são revisões preparadas pelos Grupos da Colaboração Cochrane. $\mathrm{O}$ acesso à Biblioteca Cochrane por meio da BVS está 
disponível aos países da América Latina e Caribe, exclusivamente (BVS, 2012).

O acesso às bases de dados foi por meio do site da Biblioteca Central da Faculdade de Medicina da USP, via conexão Virtual Private Network (VPN), que fornece conectividade à rede USP a partir de qualquer computador conectado à Internet.

\subsubsection{Descritores e palavras-chave}

O DeCS é um vocabulário dinâmico totalizando 30.895 descritores, sendo destes 26.664 do MeSH e 4658 exclusivamente do DeCS. Existem 2051 códigos hierárquicos de categorias DeCS em 1491 descritores MeSH.

Para uma ampla recuperação da informação, foram utilizados os descritores em Ciências da Saúde (DeCS), Medical Subject Headings (MeSH) da NLM e sinônimos descritos no Quadro 2 (BVS, 2012). 
Quadro 2 - Descrição dos componentes do P (pacientes com HAM/TSP) e I (terapêutica de interesse) do acrônimo EPICOT

((human T-lymphotropic virus type 1 associated myelopathy) OR (Human T-lymphotropic virus 1) OR (HTLV-1 infections) OR (HTLV-1) OR (HTLV I associated myelopathy) OR (tropical spastic paraparesis) OR (HTLV I associated myelopathy tropical spastic paraparesis) OR (myelopathy, human $\mathrm{T}$ lymphotropic virus type 1 associated) OR (tropical spastic paraplegia) AND (methylprednisolone OR prednisolone OR danazol OR immunoglobulin OR interferon OR lamivudine OR pentoxifylline OR (monoclonal antibody) OR hydrocortisone OR azathioprine OR sulfasalazine OR bredinin OR (interferon- $\alpha$ ) OR (alpha interferon) OR (interferon alfa) OR (interferon- $\beta 1$ ) OR (beta interferon) OR (beta 1 a interferon) OR ciclosporina OR daclizumab OR (valproic acid) OR danazol OR corticosteroids OR corticoids OR (adrenal cortex hormones) OR glucocorticoids OR steroids OR zidovudine)

As estratégias para identificação do tipo de estudo para as seguintes bases de dados são descritas nos Quadros 3 a 7 e Figuras 10 a 12: 
Quadro 3 - Estratégia MEDLINE via PubMed de busca para ensaios clínicos randomizados e controlados

Randomized controlled trial [Publication Type] OR controlled clinical trial
[Publication Type] OR randomized controlled trials [MeSH Terms] OR
OR single blind method [MeSH Terms] OR clinical trial [Publication Type]
OR clinical trials [MeSH Terms] OR (clinical* [Text Word] AND trial* [Text
Word]) OR single* [Text Word] OR double* [Text Word] OR treble* [Text
Word] OR triple* [Text Word] OR placebos [MeSH Terms] OR placebo*
[Text Word] OR random* [Text Word] OR research design [MeSH Terms]
OR comparative study [MeSH Terms] OR evaluation studies [MeSH
Terms] OR follow-up studies [MeSH Terms] OR prospective studies
[MeSH Terms] OR control* [Text Word] OR prospectiv* [Text Word] OR
volunteer* [Text Word]

Quadro 4 - Estratégia MEDLINE - Clinical Queries via PubMed de busca para ensaios clínicos randomizados e controlados

\begin{tabular}{|c|c|c|c|}
\hline Categoria & Filtro & Sensibilidade/Especificidade & $\begin{array}{c}\text { Estratégia equivalente no } \\
\text { PubMed }\end{array}$ \\
\hline therapy & specific/narrow & 93\%/97\% & $\begin{array}{c}\text { (randomized controlled } \\
\text { trial[Publication Type] OR } \\
\text { (randomized[Title/Abstract] } \\
\text { AND } \\
\text { controlled[Title/Abstract] } \\
\text { AND } \\
\text { trial[Title/Abstract])) }\end{array}$ \\
\hline
\end{tabular}


Quadro 5 - Estratégia LILACS via BIREME de busca para ensaios clínicos randomizados e controlados

(Pt randomized controlled trial) OR ( $\mathrm{Pt}$ controlled clinical trial) OR (Mh randomized controlled trials) OR (Mh random allocation) OR (Mh double blind method) OR (Mh single blind method) AND NOT (Ct animal) AND NOT (Ct human and $\mathrm{Ct}$ animal) OR (Pt clinical trial) OR (Ex E05.318.760.535\$) OR (Tw clin\$) AND (Tw trial\$) OR (Tw ensa\$) OR (Tw estud\$) OR (Tw experim\$) OR (Tw investiga\$) OR (Tw singl\$) OR (Tw simple\$) OR (Tw doubl\$) OR (Tw doble\$) OR (Tw duplo\$) OR (Tw trebl\$) OR (Tw trip\$) AND (Tw blind\$) OR (Tw cego\$) OR (Tw ciego\$) OR (Tw mask\$) OR (Tw mascar\$) OR (Mh placebos) OR (Tw placebo\$) OR (Tw random\$) OR (Tw randon\$) OR (Tw casual\$) OR (Tw acaso\$) OR (Tw azar) OR (Tw aleator\$) OR (Mh research design) AND NOT (Ct animal) AND NOT (Ct human and $\mathrm{Ct}$ animal) OR (Ct comparative study) OR (Ex E05.337\$) OR (Mh follow-up studies) OR (Mh prospective studies) OR (Tw control\$) OR (Tw prospectiv\$) OR (Tw volunt\$) OR (Tw volunteer\$) AND NOT ((Ct animal) AND NOT (Ct human and Ct animal)) 


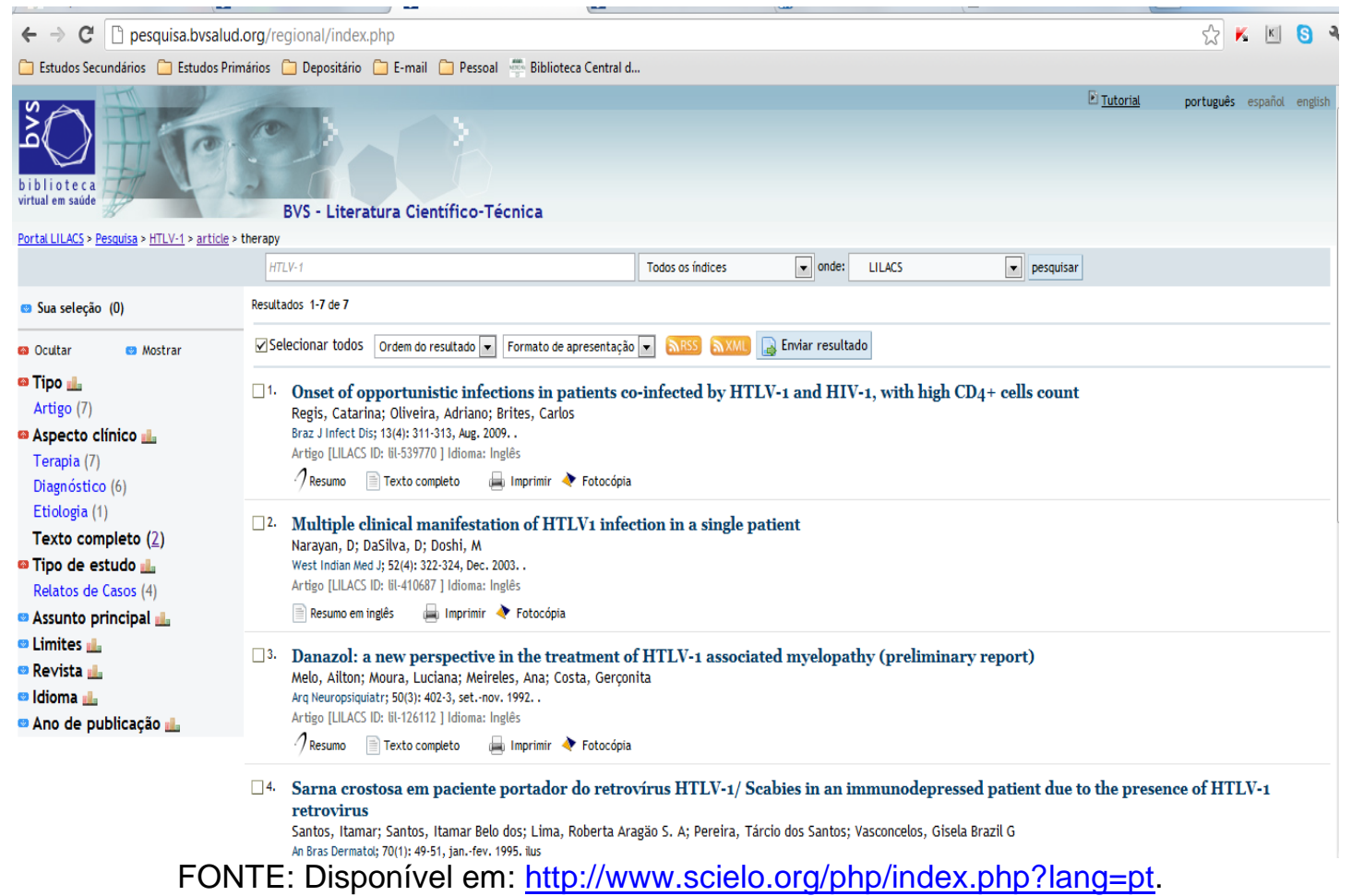

Figura 10 - Estratégia LILACS - clusters via BIREME de busca para ensaios clínicos randomizados e controlados

Quadro 6 - Estratégia EMBASE de busca para ensaios clínicos randomizados e controlados

\begin{tabular}{|c|c|}
\hline $\begin{array}{l}\# \text { Search } \\
1 . \\
2 . \\
3 . \\
4 . \\
5 . \\
6 . \\
7 . \\
8 . \\
9 . \\
10 . \\
11 . \\
12 . \\
13 . \\
14 . \\
15 . \\
16 . \\
17 . \\
18 . \\
19 . \\
20 . \\
21 . \\
22 . \\
23 . \\
24 . \\
25 .\end{array}$ & 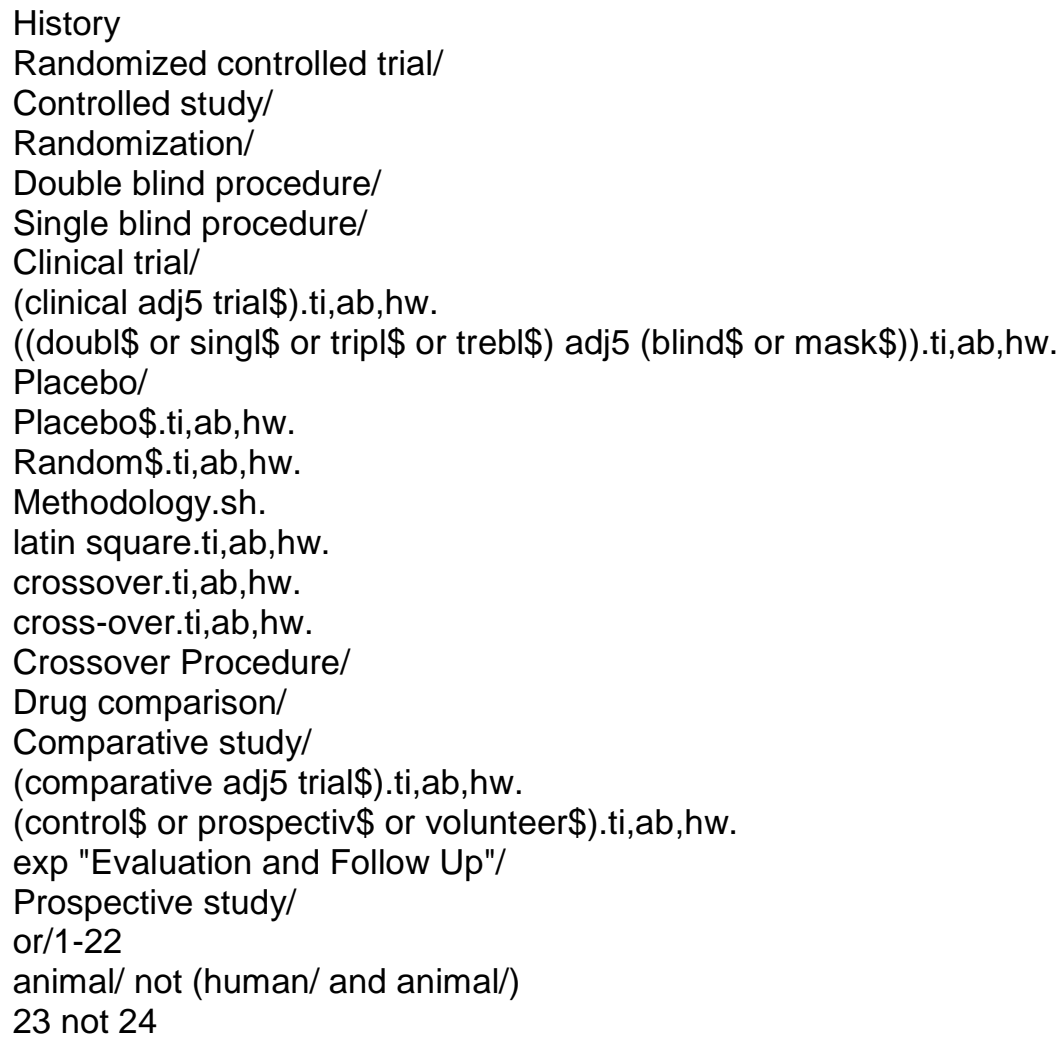 \\
\hline
\end{tabular}




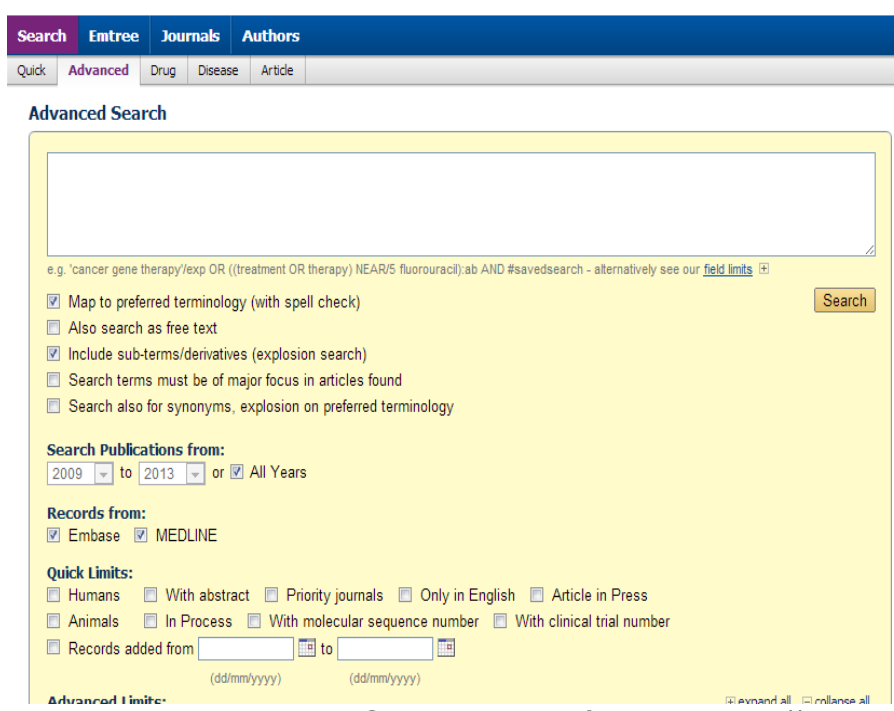

FONTE: Disponível em: http://www.embase.com/.

Figura 11 - Estratégia EMBASE - Advanced Limits de busca para ensaios clínicos randomizados e controlados

Quadro 7 - Estratégia Cochrane de busca para ensaios clínicos randomizados e controlados

((human T-lymphotropic virus type 1 associated myelopathy) OR (HTLV I associated myelopathy) OR (tropical spastic paraparesis) OR (HTLV I associated myelopathy tropical spastic paraparesis) OR (myelopathy, human T lymphotropic virus type 1 associated) OR (tropical spastic paraplegia) AND (methylprednisolone OR prednisolone OR danazol OR immunoglobulin OR interferon OR lamivudine OR pentoxifylline OR (monoclonal antibody) OR hydrocortisone OR azathioprine OR sulfasalazine OR bredinin OR (interferon- $\alpha$ ) OR (alpha interferon) OR (interferon alfa) OR (interferon- $\beta 1$ ) OR (beta interferon) OR (beta 1 a interferon) OR ciclosporina OR daclizumab OR (valproic acid) OR danazol OR corticosteroids OR corticoids OR (adrenal cortex hormones) OR glucocorticoids OR steroids OR zidovudine) 


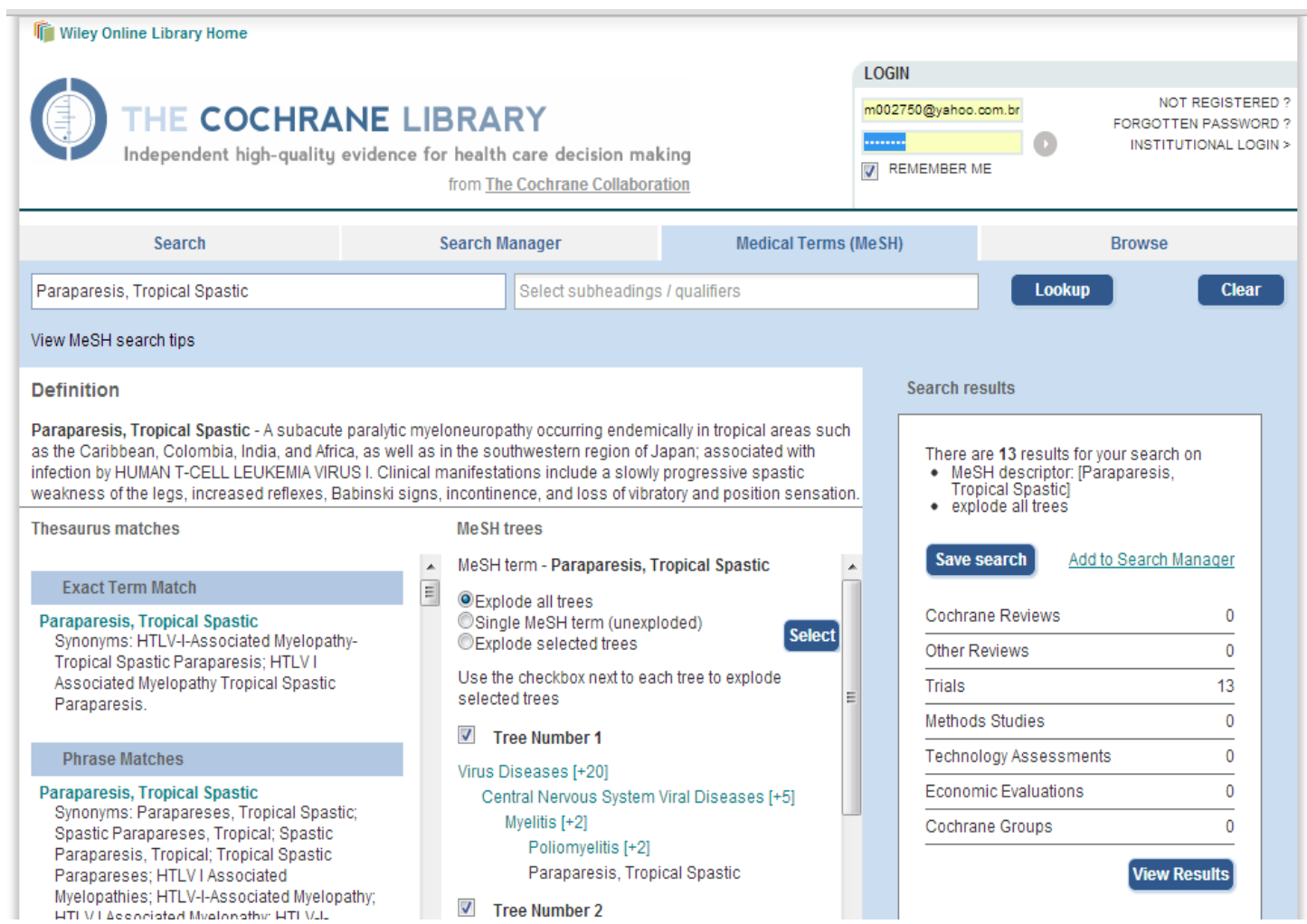

FONTE: Disponível em: http://onlinelibrary. wiley.com/cochranelibrary/search/.

Figura 12 - Estratégia Cochrane - Limits de busca para ensaios clínicos randomizados e controlados

As listas de referências de todos os ECRs também foram checadas à procura de outros ECRs não localizados nas bases de dados acima.

\subsection{Localização dos estudos}

Os títulos e os resumos de todas as publicações identificadas na busca eletrônica e manual foram inicialmente avaliados. Após primeira seleção, os estudos que preencheram os critérios de inclusão e aqueles que não puderam ser descartados (por falta de informações sobre a metodologia) 
foram obtidos na forma de texto completo. A seguir, os artigos foram lidos na íntegra e classificados em selecionados ou não para análise, conforme critérios de inclusão, qualidade metodológica e possibilidade de extração de dados (Figura 13).

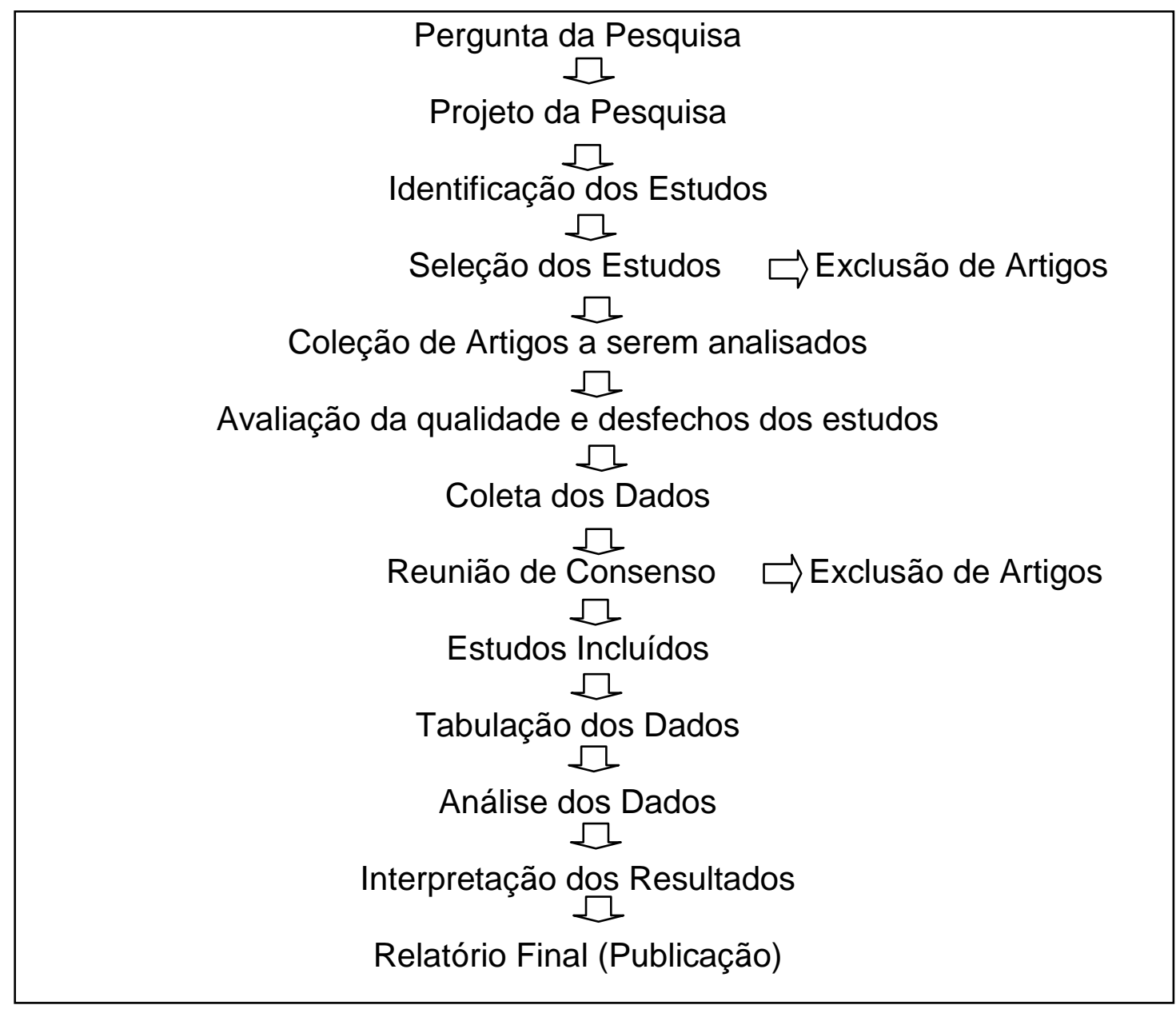

FONTE: Adaptado de Centre for Reviews and Dissemination, 2009.

Figura 13 - Fluxograma da estratégia da revisão sistemática 


\subsection{Avaliação da qualidade metodológica dos estudos}

Desde a década de 1970, várias organizações usam diferentes sistemas para classificar a qualidade das evidências e a força de recomendação dos estudos. As mesmas evidências e recomendações podem ser classificadas de diferentes maneiras, dependendo do sistema utilizado. A maior parte dessas classificações é subjetiva, e, devido à heterogeneidade entre elas, muitas vezes, tornam-se limitadas análises e comparações entre os estudos (Guyatt GH., et al., 2008).

Os estudos selecionados para esta revisão sistemática foram classificados segundo a qualidade da evidência e a força da recomendação, segundo a classificação do Oxford Centre for Evidence-based Medicine Levels of Evidence (Figura 14) (Phillips B et al.; 2009) e a escala de Jadad (Jadad et al., 1996). 


\begin{tabular}{|c|c|c|c|}
\hline \multicolumn{4}{|c|}{$\begin{array}{l}\text { Nivel de Evidência Cientifica por Tipo de Estudo - "Oxford Centre for } \\
\text { Evidenoe-based Medicine" - última ałtualzaçăo maio de } 2001\end{array}$} \\
\hline $\begin{array}{c}\text { Grau de } \\
\text { Recomendação }\end{array}$ & $\begin{array}{l}\text { Nivel de } \\
\text { Evidêneia }\end{array}$ & $\begin{array}{l}\text { Tratamentol } \\
\text { Prevençẫo - Etiologia }\end{array}$ & Diagnóstico \\
\hline \multirow{3}{*}{ A } & $1 \mathrm{~A}$ & $\begin{array}{l}\text { Revisalo Sistemática (com } \\
\text { homogeneidade) } \\
\text { de Ensaios Clinicos Controlados e } \\
\text { Randomizados }\end{array}$ & $\begin{array}{l}\text { Revisto Sistemática (com homogeneidade) } \\
\text { de Estudos Diagnósticos nivel } 1 \text { Critério } \\
\text { Diagnósfico de estudos nivel 1B, em } \\
\text { dferentes centros clinicos }\end{array}$ \\
\hline & $1 \mathrm{~B}$ & $\begin{array}{l}\text { Ensaio Clinico Controlado e } \\
\text { Randomizado com Intervalo de } \\
\text { Confiança Estreito }\end{array}$ & $\begin{array}{l}\text { Coorle validada, com bom padraà de } \\
\text { referéncia Critério Diagnóstico testado em um } \\
\text { único centro clinico }\end{array}$ \\
\hline & $1 \mathrm{C}$ & $\begin{array}{l}\text { Resultados Terapéuficos do tipo "tudo ou } \\
\text { nada" }\end{array}$ & $\begin{array}{l}\text { Sensibilidade e Especificidade próximas de } \\
100 \%\end{array}$ \\
\hline \multirow{5}{*}{ B } & $2 \mathrm{~A}$ & $\begin{array}{l}\text { Revisăo Sistemática (com } \\
\text { homogeneidade) } \\
\text { de Estudos de Coorte }\end{array}$ & $\begin{array}{l}\text { Revisto Sistemática (com homogeneidade) } \\
\text { de estudos diagnósticos de nivel > } 2\end{array}$ \\
\hline & $2 B$ & $\begin{array}{l}\text { Estudo de Coorte (incluindo Ensaio } \\
\text { Clinico } \\
\text { Randomizado de Menor Qualidade) }\end{array}$ & $\begin{array}{l}\text { Coorłe Exploratária com bom padrăo de } \\
\text { Referéncia Critério Diagnósfico derivado ou } \\
\text { validado em amostras fragmentadas } \\
\text { ou banco de dados }\end{array}$ \\
\hline & $2 \mathrm{C}$ & $\begin{array}{l}\text { Observaçăo de Resultados Terapéuticos } \\
\text { (outcomes research) } \\
\text { Estudo Ecológico }\end{array}$ & \\
\hline & $3 \mathrm{~A}$ & $\begin{array}{l}\text { Revisăo Sistemática (com } \\
\text { homogeneidade) } \\
\text { de Estudos Caso-Controle }\end{array}$ & $\begin{array}{l}\text { Revisło Sistemática (com homogeneidade) } \\
\text { de estudos diagnósticos de nivel > 3B }\end{array}$ \\
\hline & $3 \mathrm{~B}$ & Estudo Caso-Controle & $\begin{array}{l}\text { Seleç̧̇o năo consecutiva de casos, ou } \\
\text { padrało de referência aplicado de forma } \\
\text { pouco consistente }\end{array}$ \\
\hline c & 4 & $\begin{array}{l}\text { Relato de Casos (induindo Coorte ou } \\
\text { Caso-Controle de menor qualidade) }\end{array}$ & $\begin{array}{l}\text { Estudo caso-controle; ou padrăo de referéncia } \\
\text { pobre ou nâo independente }\end{array}$ \\
\hline D & 5 & $\begin{array}{r}\text { Opiniảo desprovida de avaliaçâo critica ou } \\
\text { ou estuc }\end{array}$ & $\begin{array}{l}\text { baseada em matérias básicas (estudo fisiológico } \\
\text { com animais) }\end{array}$ \\
\hline
\end{tabular}

FONTE: Disponível em: http://portal.saude.gov.br/portal/arquivos/pdf/tabela_nivel_evidencia.pdf. Figura 14 - Níveis de Evidência Científica segundo a classificação de Oxford Centre for Evidence-Based of Medicine

Jadad et al. (1996) descreveram uma classificação que confere um ponto para cada resposta positiva, caso o estudo tenha sido descrito como randomizado, duplo-cego e contenha a descrição das perdas da amostra estudada. Adicionalmente, confere com outro ponto se houver propriedade 
na randomização e no mascaramento e, ainda, caso haja descrição de perda de seguimento menor ou igual a $20 \%$ da amostra inicial:

a) Para a randomização: o método de geração da sequência aleatória foi considerado apropriado se permitiu a cada participante do estudo ter a mesma chance de receber cada intervenção e se o investigador não pode prever qual seria o próximo tratamento. Métodos de geração da sequência usando data de aniversário, data de admissão, número de registro no hospital ou alternância entre os grupos foram considerados inadequados;

b) Para o mascaramento duplo-cego: um estudo foi considerado duplo-cego se o termo duplo-cego foi usado. O método foi considerado apropriado se o responsável pelo cuidado do paciente e tampouco o paciente tiveram como identificar o tipo de tratamento ministrado a cada um dos sujeitos estudados ou, na ausência dessa declaração, se o uso de placebos idênticos ou imitações foi mencionado;

c) Para avaliação de perdas e exclusões, considerou-se a descrição da existência dos participantes que entraram no estudo, mas não completaram o período de observação, ou quando os dados de toda a população estudada não foram incluídos na análise. Adicionalmente, o número e as razões para perdas em cada grupo tinham que ser declarados. Se não houvesse perdas, tal 
informação deveria ter sido mencionada no artigo. Se não houvesse descrição de perdas, atribuiu-se nota zero a esse item.

O total do escore atribuído a cada estudo, portanto, poderia variar entre 0 e 5. Escore maior ou igual a três revela estudo com qualidade metodológica adequada.

\subsection{Coleta dos dados}

Foram utilizados três formulários padronizados (Anexo A, B e C), baseados no Cochrane Handbook for Systematic Reviews of Interventions (Higgins; Green, 2011) e nas recomendações para a realização de revisões sistemáticas propostas pela Associação Médica Brasileira - Projetos Diretrizes (Nobre et al., 2003), para extração das seguintes informações:

a) Identificação do estudo (título, ano de publicação e autores);

b) Métodos: desenho do estudo, descrição do processo de randomização e mascaramento, existência de análise por intenção de tratar e de sigilo de alocação, e duração do estudo;

c) Participantes: tamanho da amostra, idade, sexo, país de origem dos sujeitos, via de transmissão da infecção por HTLV, critério diagnóstico de HAM/TSP, história clínica e perdas de seguimento; 
d) Intervenções: tipo e duração da intervenção;

e) Desfechos: primários ou secundários, como descritos nos itens 3.5.1 e 3.5.2, a seguir.

\subsection{Análise estatística}

Para dados dicotômicos, foi calculado o risco relativo (proporção de eventos no grupo de tratamento em relação à proporção de eventos no grupo-controle) com intervalo de confiança de $95 \%$. Tais estimativas foram calculadas a partir da abordagem de análise por intenção de tratar. Os efeitos estimados foram combinados, quando possível, usando o modelo de efeito randômico, que considera os resultados desviantes, em função de heterogeneidades de natureza clínica e metodológica, mesmo quando desconhecidos.

Para dados contínuos, esses foram expressos como médias e desviospadrão, com cálculo da proporção de média ponderada com intervalo de confiança de 95\% (Higgins; Green, 2011). 


\subsubsection{Heterogeneidade}

As causas potenciais de heterogeneidade entre os estudos foram exploradas e analisadas quando possível. A análise de sensibilidade foi planejada para investigar a influência da qualidade dos ensaios, incluindo a randomização nos resultados gerais.

As inconsistências entre os estudos somados na metanálise foram quantificadas, quando possível, utilizando-se o teste de heterogeneidade $\mathrm{I}^{2}=$ [(Q - df $) / Q] \times 100 \%$, sendo $Q$ o qui-quadrado e, df (degrees of freedom) o grau de liberdade. De 0\% a 40\% considerou-se não ser importante; 30\% a $60 \%$, como representando moderada heterogeneidade; $50 \%$ a $90 \%$, como grande heterogeneidade; e $75 \%$ a $100 \%$, como considerável heterogeneidade (Higgins; Green, 2011).

\subsubsection{Análise de sensibilidade}

A análise de sensibilidade foi planejada para explorar as causas de heterogeneidade dos resultados entre os estudos. Os seguintes fatores foram incluídos na análise de sensibilidade: 
- Qualidade de ocultação de alocação (adequada, duvidosa ou inadequada);

- Método duplo-cego (adequado, duvidoso, inadequado ou não utilizado);

- Análise utilizando tanto o modelo de efeito fixo e o modelo de efeito randômico.

\subsection{Metanálises}

Quando os dados de mais de um estudo são homogêneos em relação à metodologia empregada, seus valores podem ser combinados em uma metanálise, com ajuda do software Review Manager 5.0, desenvolvido pela Cochrane Collaboration (Review Manager, 2011).

\subsection{Atualização e aprimoramento da revisão sistemática}

Após o término da revisão sistemática, inicialmente concluída em dezembro de 2011, quando da elaboração do projeto, os dados foram atualizados anualmente em 31/01/2012 e 31/01/2013, data esta coincidente com a última busca de ECRs sobre o tema proposto. 


\subsection{Aspectos éticos}

- Esta dissertação avaliou dados secundários de ensaios clínicos, não tendo havido, portanto, obtenção de assinatura de termo de consentimento livre e esclarecido pelos participantes. 0 anonimato dos sujeitos nos diferentes estudos incluídos na pesquisa e a confidencialidade no manejo das informações obtidas foram mantidos ao longo de todo o trabalho;

- $\quad$ o protocolo de pesquisa foi aprovado pela Comissão de Ética e Pesquisa do Departamento de Moléstias Infecciosas e Parasitárias da FMUSP, e pela Comissão de Ética em Pesquisa da FMUSP;

- $\quad$ Conflitos de interesse: nenhum a ser declarado. 
4 Resultados 


\section{RESULTADOS}

\subsection{Seleção dos estudos}

Inicialmente, 106 estudos foram identificados por meio das bases de dados eletrônicas mencionadas anteriormente e dois outros por busca manual, totalizando 108 estudos. Esses foram selecionados, em primeira análise, pela leitura de títulos e resumos. Os resultados da busca e seleção, e análise dos estudos são esquematicamente apresentados na Figura 15.

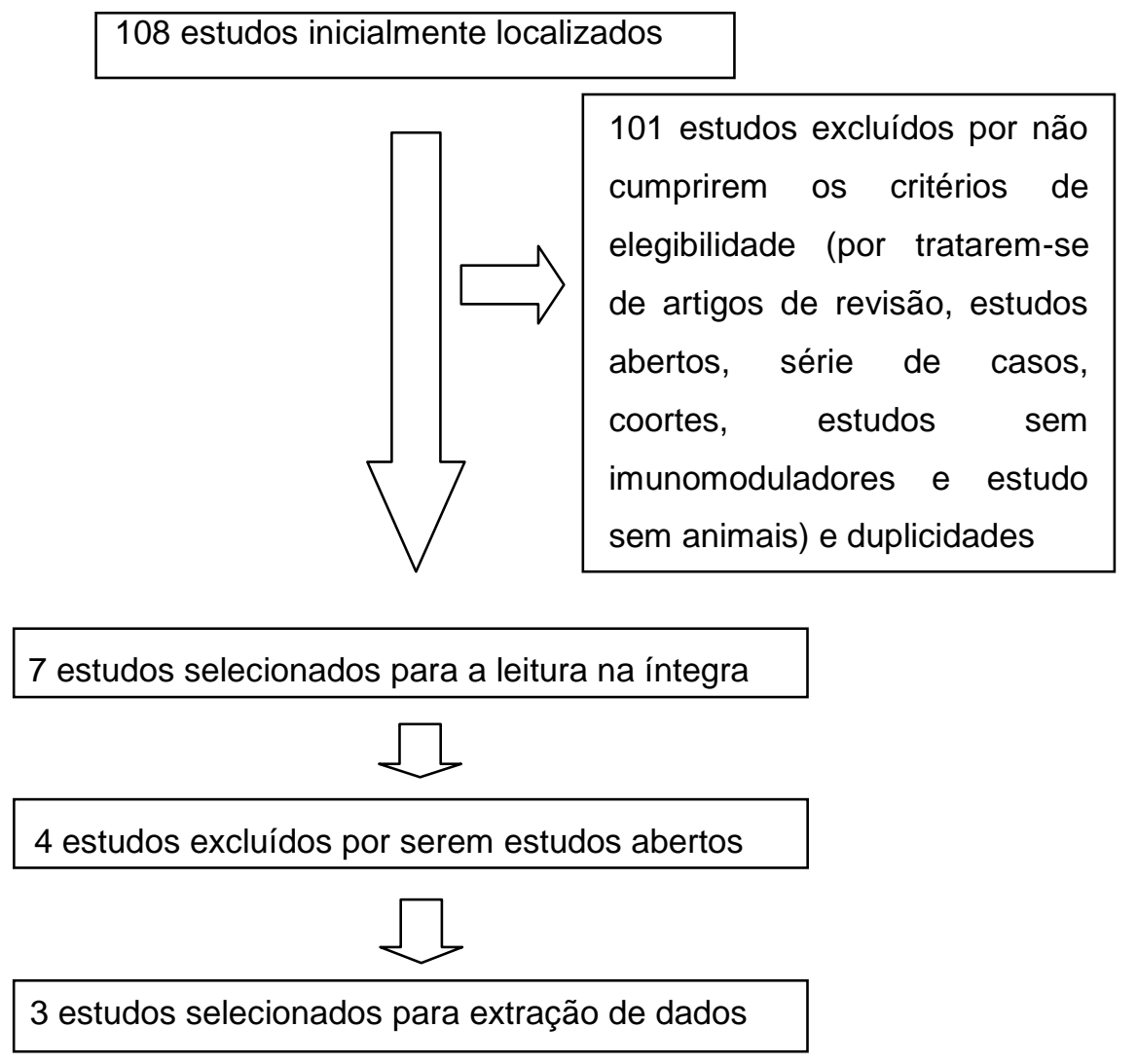

Figura 15 - Fluxograma dos resultados da busca e seleção dos ECRs 
Desses 108 identificados, apenas sete estudos foram considerados elegíveis para possível inclusão nesta revisão e foram avaliados por meio de leitura de texto completo. Após reunião de consenso, quatro estudos foram excluídos: Harrington WJ Jr et al., 1991; Gout O et al., 1991; Kuroda Y et al., 1991; e Yamasaki K et al., 1997 pelos motivos demonstrados no Quadro 8.

Quadro 8 - Estudos excluídos da revisão sistemática após reunião e decisão consensual

\begin{tabular}{|c|c|}
\hline ESTUDO & RAZÃO DA EXCLUSÃO \\
\hline Harrington WJ Jr et al., 1991 & Estudo aberto com danazol \\
\hline Gout O et al., 1991 & Estudo aberto com zidovudina \\
\hline Kuroda Y et al., 1991 & Estudo aberto com gamaglobulina \\
\hline Yamasaki K et al., 1997 & Estudo aberto com interferon $\alpha$ \\
\hline
\end{tabular}

Dessa forma, três estudos preencheram os critérios mínimos requeridos metodologicamente e foram incluídos nesta revisão: Kuroda et al., 1992; Izumo et al., 1996; e Taylor et al., 2006.

\subsection{Desenho dos estudos}

Todos os estudos incluídos tratam-se de ensaios clínicos randomizados e controlados. 


\subsection{Tipos de desfechos mensurados, participantes e duração dos ECRs}

Kuroda et al. (1992) avaliaram 16 pacientes submetidos ao tratamento com interferon $\alpha$, sendo que somente quatro desses foram randomizados; no grupo randomizado, o paciente e investigador não conheciam a que grupo 0 paciente pertencia, tendo sido esses divididos em três grupos, que receberam diferentes doses, um paciente recebeu 0,3 milhões de UI, outro recebeu 1,0 milhão de UI e os dois restantes receberam 3,0 milhões de UI; todos pela via intramuscular uma vez por dia e durante 28 dias consecutivos. Os desfechos avaliados durante e após o tratamento foram: a incapacidade funcional nos membros inferiores, principalmente a relacionada à marcha e força (avaliada pela Kurtzke Expanded Disability Status Scale - EDSS); ocorrência de eventos adversos da terapêutica e resultados de exames laboratoriais (hemograma completo, função hepática, imunofenotipagem de linfócitos T no sangue periférico, dosagem de imunoglobulinas séricas e de IgG no LCR, e determinação de título de anticorpo anti-HTLV no LCR e no soro).

Foram incluídos neste estudo dois homens e duas mulheres, com idades entre 47 e 64 anos, com 2 a 34 anos de evolução da HAM/TSP, com paraparesia espástica progressiva sem episódios de remissão espontânea, sem evidência radiológica de compressão da medula espinhal e presença de

anticorpos anti-HTLV-1 no soro e no LCR; um paciente apresentava 3 pontos na escala EDSS, dois pacientes 6 pontos e outro paciente 7 pontos. 
Não foram utilizados outros medicamentos, como antivirais e outros imunomoduladores, simultaneamente à intervenção estudada.

Izumo et al. (1996) avaliaram 48 pacientes submetidos ao tratamento com interferon $\alpha$, divididos em três grupos, que receberam diferentes doses do fármaco: 15 receberam 0,3 milhões de UI, 17 receberam 1,0 milhão de UI e 16 receberam 3,0 milhões de UI; todos pela via intramuscular, uma vez por dia e durante 28 dias consecutivos. Os desfechos avaliados antes, durante e até quatro semanas após o término da intervenção foram: a incapacidade funcional nos membros inferiores, principalmente a relacionada à marcha (avaliada pela escala Osame Motor Disability Score - OMDS); distúrbio urinário, avaliado por meio do aumento da frequência miccional, incontinência urinária e resíduo miccional (escala de 0 a 3, 0: normal, 1: leve, 2: moderado e 3: grave); resultados de exames laboratoriais (dosagem de $\lg G$, IgM, IgA, C3 e C4 séricos, determinação de título de anticorpos antiHTLV circulantes, número de células $C D 4+/ \mathrm{mm}^{3}$ e $C D 8+/ \mathrm{mm}^{3}$ no sangue periférico, à época denominada células OKT4 e OKT8, respectivamente, e resultados da análise do LCR); além da ocorrência de eventos adversos da terapêutica.

A evolução da disfunção motora foi classificada em excelente (melhora de dois ou mais graus na escala OMDS), boa (melhora de um grau ou sem melhora, mas com melhora aparente em, pelo menos, duas outras disfunções), média (melhora da disfunção motora, mas sem mudança na escala OMDS ou sem melhora na disfunção motora, com melhora em um ou 
mais itens examinados), pobre (paciente sem melhora) e nula (piora do quadro clínico).

Foram incluídos nesse estudo 16 homens e 32 mulheres, com idades entre 20 e 75 anos, com 2 a 34 anos de evolução da HAM/TSP, de acordo com os critérios clínicos e laboratoriais da OMS e sem uso de imunomoduladores nas duas semanas anteriores à intervenção; 36 pacientes apresentavam escores variando de 0 a 6 pontos na escala OMDS, três pacientes de 7 a 8 pontos, quatro pacientes de 9 a 10 pontos e cinco pacientes de 11 a 13 pontos. O uso de outros medicamentos, exceto antivirais e imunomoduladores, foi permitido se a posologia fosse a mesma antes, durante e depois da intervenção com interferon $\alpha$. Antipirético também foi permitido para o tratamento da febre.

Taylor et al. (2006), por sua vez, avaliaram 16 pacientes, sendo que oito deles receberam $300 \mathrm{mg}$ de zidovudina e $150 \mathrm{mg}$ de lamivudina, pela via oral, duas vezes por dia e oito receberam placebo nas primeiras 24 de 48 semanas do estudo, distribuídos de forma randomizada e avaliadores duplocegos. Nas últimas 24 semanas, o estudo foi aberto e todos os pacientes receberam $300 \mathrm{mg}$ de zidovudina e $150 \mathrm{mg}$ de lamivudina, pela via oral, duas vezes por dia. Os desfechos avaliados foram: a incapacidade funcional nos membros inferiores, principalmente a relacionada à marcha (avaliada pela escala Osame Motor Disability Score - OMDS); a dor em membros inferiores por meio de uma escala visual; distúrbio urinário por meio do aumento da frequência miccional e noctúria; e resultado de exames laboratoriais (hemograma completo, bioquímica plasmática, carga proviral de 
HTLV-1 em células mononucleares periféricas e fenotipagem dos linfócitos T periféricos).

Foram incluídos nesse estudo 12 pacientes de Londres e quatro pacientes de Kagoshima, sendo cinco homens e 11 mulheres, 10 descendentes de negros africanos do Caribe, um com ascendência indígena, quatro com ascendência japonesa e um com ascendência persa, idades entre 18 e 75 anos, e com 1 a 19 anos de manifestações clínicas relacionadas à HAM/TSP (média de 9 anos); seis pacientes apresentavam escores variando de 0 a 4 pontos na escala OMDS, sete pacientes de 5 a 8 pontos e três pacientes de 9 a 13 pontos. Todos tinham HAM/TSP (de acordo com os critérios clínicos e laboratoriais da OMS), não incluíam gestantes ou relato de uso de outras medicações, tais como corticosteroides, quatro semanas prévias à intervenção. Foram excluídos os pacientes com infecção pelo HIV, com uso prévio de zidovudina ou lamivudina ou aqueles com anormalidades nos exames laboratoriais hematológicos, na função renal ou função hepática.

A Tabela 2 sintetiza as características dos ECRs avaliados. 
Tabela 2 - Síntese das características dos clínicos randomizados e controlados de imunomoduladores para o tratamento de HAM/TSP

\begin{tabular}{|c|c|}
\hline $\begin{array}{l}\text { Referência } \\
\text { (ano) }\end{array}$ & Critérios de inclusão \\
\hline $\begin{array}{l}\text { Kuroda et al. } \\
\text { (1992) }\end{array}$ & $\begin{array}{l}\text { Pacientes com } \\
\text { paraparesia espástica } \\
\text { progressiva sem episódios } \\
\text { de remissão espontânea, } \\
\text { sem evidência radiológica } \\
\text { de compressão da medula } \\
\text { espinhal e presença de } \\
\text { anticorpos anti-HTLV-1 no } \\
\text { soro e no LCR; idades } \\
\text { entre } 47 \text { e } 64 \text { anos; com } 2 \\
\text { a } 34 \text { anos de evolução da } \\
\text { HAM/TSP; escores } \\
\text { variando de } 3 \text { a } 7 \text { pontos } \\
\text { na escala EDSS. }\end{array}$ \\
\hline
\end{tabular}

Pacientes com HAM/TSP de acordo com os dados clínicos e laboratoriais da OMS; presença de anticorpos anti-HTLV-1 no soro e no LCR; sem uso de imunomoduladores

Izumo et al. (1996) nas duas semanas anteriores à intervenção; antipirético foi permitido para o tratamento da febre; idades entre $20 \mathrm{e}$ 75 anos; com 2 a 34 anos de evolução da HAM/TSP; escores variando de 0 a 13 pontos na escala OMDS.

Critérios de Intervenção exclusão

Uso de outros medicamentos, como antivirais e imunomodulares.

Uso de outros medicamentos, como antivirais e imunomodulares. (n) 


\subsection{Validade interna dos estudos incluídos}

Os três estudos selecionados foram classificados segundo a classificação do Oxford Centre for Evidence-based Medicine Levels of Evidence e a escala de Jadad (Tabela 3).

Tabela 3 - Síntese da análise da validade interna dos ensaios clínicos randomizados e controlados de imunomoduladores para o tratamento de HAM/TSP

\begin{tabular}{|c|c|c|c|c|c|c|c|}
\hline $\begin{array}{l}\text { Referência } \\
\text { (ano) }\end{array}$ & $\begin{array}{c}\text { Grupos } \\
\text { intervenção } \\
\text { e } \\
\text { controle }\end{array}$ & $\begin{array}{l}\text { Evidência/grau } \\
\text { de recomen- } \\
\text { dação de } \\
\text { acordo com } \\
\text { níveis de } \\
\text { evidência } \\
\text { científica } \\
\text { segundo a } \\
\text { classificação } \\
\text { de Oxford } \\
\text { Centre for } \\
\text { Evidence- } \\
\text { Based of } \\
\text { Medicine }\end{array}$ & $\begin{array}{c}\text { Escala } \\
\text { de } \\
\text { Jadad }\end{array}$ & $\begin{array}{l}\text { Número de } \\
\text { sujeitos no } \\
\text { grupo } \\
\text { intervenção }\end{array}$ & $\begin{array}{l}\text { Número de } \\
\text { sujeitos no } \\
\text { grupo } \\
\text { placebo }\end{array}$ & $\begin{array}{l}\text { Tempo de } \\
\text { seguimen- } \\
\text { to }\end{array}$ & $\begin{array}{l}\text { Perdas de } \\
\text { seguimen- } \\
\text { to }\end{array}$ \\
\hline $\begin{array}{l}\text { Kuroda et } \\
\text { al. (1992) }\end{array}$ & $\begin{array}{c}\text { interferon a } \\
\text { em } \\
\text { diferentes } \\
\text { doses }\end{array}$ & $\mathrm{A} / 1 \mathrm{C}$ & 3 & 4 & - & 28 dias & - \\
\hline $\begin{array}{l}\text { Izumo et } \\
\text { al. (1996) }\end{array}$ & $\begin{array}{c}\text { interferon a } \\
\text { em } \\
\text { diferentes } \\
\text { doses }\end{array}$ & $A / 1 C$ & 5 & 48 & - & 28 dias & 8 \\
\hline $\begin{array}{l}\text { Taylor et } \\
\text { al. (2006) }\end{array}$ & $\begin{array}{c}\text { zidovudina e } \\
\text { lamivudina } \\
\text { versus } \\
\text { placebo }\end{array}$ & $A / 1 B$ & 5 & 8 & 8 & $\begin{array}{c}24 \\
\text { semanas }\end{array}$ & 1 \\
\hline
\end{tabular}

\subsection{Comprometimento funcional}

A OMDS é uma escala que mede a incapacidade funcional nos

membros inferiores, principalmente relacionada à marcha, assim como a 
dificuldade em realizar transferências e marcha com independência. Os escores variam de 0 (sem dificuldade para andar e correr) a 13 (acamado).

Izumo et al. (1996) avaliaram três grupos e o grupo com 16 pacientes (sete homens e nove mulheres), que recebeu 3,0 milhões de UI de interferon $\alpha$, apresentou melhores resultados (melhora na escala OMDS ou melhora na disfunção motora sem alteração na escala OMDS), tanto na quarta semana de intervenção, como quatro semanas após o término do tratamento, quando comparados ao grupo que recebeu a posologia de 0,3 milhões de UI ( $p=$ 0,019 e $p=0,027$, respectivamente). Não houve diferença estatisticamente significativa entre os pacientes desse grupo com o que recebeu 1,0 milhão de UI, tampouco entre 1,0 milhão de UI e 0,3 milhões de interferon $\alpha$. É importante salientar que, nesse estudo, não foi observada diferença significativa quanto ao tempo de evolução de HAM/TSP.

Não há informação sobre o uso concomitante de outros medicamentos nesse estudo.

No estudo de Taylor et al. (2006), não houve diferença estatisticamente significativa na melhora na escala OMDS e nem na dor, quando comparados os oito pacientes que receberam $300 \mathrm{mg}$ de zidovudina e $150 \mathrm{mg}$ de lamivudina, com os oito pacientes que receberam placebo nas primeiras 24 semanas do estudo ( $p=0,99$ em ambos os desfechos).

Kuroda et al. (1992), por sua vez, avaliaram dois pacientes (um homem e uma mulher) que receberam 3,0 milhões de $U$ I de interferon $\alpha$, um paciente do sexo masculino que recebeu 1,0 milhão de UI de interferon $\alpha$; e um paciente do sexo feminino que recebeu 0,3 milhões de $\mathrm{UI}$ interferon $\alpha$. 
Os dois pacientes que receberam 3,0 milhões de $\mathrm{Ul}$ de interferon $\alpha$ apresentaram melhores resultados (melhora na força do extensor femoral, com média de melhora em $65,5 \%$ na força medida em $\mathrm{kg}$ e redução no tempo medido em segundos com média de melhora de $58 \%$ para caminhar $20 \mathrm{~m}$ ) durante e após a intervenção, quando comparados ao grupo que recebeu a posologia de 0,3 milhões UI ou 1,0 milhão de UI. Não foi citado o poder estatístico calculado para o estudo. Salientaram os autores que a média dos escores da EDSS obtida da intervenção foi igual a zero no grupo que recebeu a posologia de 0,3 milhões de UI e de 1,0 milhão de UI, denotando falta de resposta à intervenção.

Cabe ressaltar que a EDSS é uma escala que possui vinte itens para os quais são atribuídos escores variando de 0 a 10 , com pontuação aumentando em meio ponto conforme o grau de incapacidade de deambulação do paciente. Avalia sete sistemas funcionais: piramidal, cerebelar, tronco cerebral, sensitivo, visual e mental; analisa a marcha e inclui crescentes alterações na deambulação, uso de apoio unilateral ou bilateral, restrição à cadeira de rodas e ao leito.

\subsection{Distúrbio urinário}

Nesse quesito, no estudo de Izumo et al. (1996), o grupo que recebeu 3,0 milhões de $\mathrm{UI}$ de interferon a apresentou melhores resultados do que o 
grupo que recebeu a posologia de 0,3 milhões de unidades, entretanto, sem descrição de informações estatísticas relevantes ( $p$, médias e desviospadrão). Na avaliação global (baseada na melhora da disfunção motora, distúrbios urinários e outros sinais neurológicos), a melhora da resposta de média a excelente foi observada em $66,7 \%$ no grupo que recebeu 3,0 milhões de UI de interferon a após 4 semanas do término da intervenção, significativamente diferente do verificado nos demais grupos $(p=0,027)$.

No estudo de Taylor et al. (2006), não houve diferença estatisticamente significativa na melhora na frequência urinária ou noctúria, comparando-se os oito pacientes que receberam $300 \mathrm{mg}$ de zidovudina e $150 \mathrm{mg}$ de lamivudina, aos oito pacientes que receberam placebo nas primeiras 24 semanas do estudo ( $p=0,93$ para frequência urinária e $p=0,41$ para noctúria).

Finalmente, no estudo de Kuroda et al. (1996), esse desfecho não foi avaliado.

\subsection{Exames laboratoriais}

No estudo de Izumo et al. (1996), não houve diferença estatisticamente significativa entre os grupos quanto às alterações nas concentrações séricas de IgG, IgM, IgA, C3 e C4, tampouco nos títulos de anticorpos anti-HTLV, número de linfócitos OKT4 e OKT8, e alterações no LCR (título de 
anticorpos anti-HTLV, proteinorraquia e número de células). O grupo que recebeu 3,0 milhões de UI de interferon a apresentou mais leucopenia, plaquetopenia e aumento da relação TGO/TGP, do que o grupo que recebeu a posologia de 0,3 milhões de unidades $(p=0,037)$. Os efeitos adversos ocorreram de acordo com a dose utilizada; entretanto, a maioria dos pacientes pode continuar utilizando o interferon $\alpha$ até o término da intervenção proposta.

No estudo de Kuroda et al. (1992), os pacientes que receberam 3,0 milhões de UI de interferon a apresentaram redução do número de leucócitos no sangue periférico $(p<0,005)$; verificou-se, ainda, redução das concentrações de IgG no LCR e de IgG, IgA e IgM séricas, contudo, sem diferença estatisticamente significativa.

No estudo de Taylor et al. (2006), não se observaram diferenças estatisticamente significativas na redução da carga proviral de HTLV-1 ( $p=$ $0,92)$, no número total de linfócitos $(p=0,07)$, de linfócitos $\operatorname{T} C D 3+(p=0,47)$, linfócitos T CD4+ $(p=0,55)$ e linfócitos $\operatorname{TCD} 8+(p=0,15)$ periféricos, comparando-se os oito pacientes que receberam $300 \mathrm{mg}$ de zidovudina e $150 \mathrm{mg}$ de lamivudina, aos oito pacientes que receberam placebo nas primeiras 24 semanas do estudo. Também não houve diferença estatisticamente significativa na expressão do marcador de ativação CD69 $(p=0,73)$, do marcador de proliferação $\operatorname{CD71}(p=0,97)$ e na expressão do receptor de IL-2 (CD25) $(p=0,58)$. Ao lado disso, não foram observadas alterações importantes na bioquímica sérica. 


\subsection{Efeitos adversos}

No estudo de Izumo et al. (1996), os efeitos adversos mais comuns foram febre e anorexia; quanto às diferentes doses, os dados não apresentaram significância estatística na ocorrência desse desfecho.

No estudo de Taylor et al. (2006), identificou-se piora do quadro clínico em um paciente do grupo que recebeu zidovudina e lamivudina, quando reavaliado na oitava semana da intervenção. Nessa ocasião, foi acrescentado ao seu tratamento interferon $\alpha$ até a vigésima semana e a zidovudina descontinuada devido à anemia hemolítica autoimune. Nenhum efeito adverso foi atribuído à lamivudina. De forma geral, as medicações foram bem toleradas e constatou-se boa adesão dos sujeitos à intervenção.

Finalmente, no estudo de Kuroda et al. (1996), a ocorrência desse desfecho não apresentou significância estatística. 


\section{Discussão}




\section{DISCUSSÃO}

A HAM/TSP é a manifestação neurológica mais descrita da infecção pelo HTLV-1 e causa um importante comprometimento funcional, consequentemente, afastamento temporário ou definitivo das atividades laborativas e redução da qualidade de vida.

Dadas as exigências atuais por melhores cuidados de saúde, os profissionais da área frequentemente empregam diferentes terapêuticas disponíveis para tratar os pacientes com HAM/TSP, além de valerem-se de intervenções não medicamentosas de abordagem multidisciplinar, visando diminuir a incapacidade e melhorar a qualidade de vida dos pacientes.

Ainda hoje, existem muitas controvérsias sobre qual seria a melhor intervenção e, quando indicado, qual o melhor imunomodulador para o tratamento da HAM/TSP. Essa controvérsia torna-se ainda maior quando o paciente não apresenta todos os critérios que confirmem o diagnóstico de HAM/TSP, de acordo com os critérios clínicos e laboratoriais definidos pela OMS, e, particularmente, quando o paciente apresenta comorbidades. Faltam conhecimentos sobre os mecanismos fisiopatológicos relacionados ao desenvolvimento da HAM/TSP e, consequentemente, sobre o papel dos imunomoduladores na intervenção medicamentosa dessa condição. Dado que essa opção terapêutica é a mais utilizada, mesmo na falta de evidências, a questão fundamental ainda permanece: qual dos 
medicamentos imunomoduladores seria mais eficaz no tratamento de pacientes adultos com HAM/TSP?

Nesta revisão sistemática, o objetivo foi tentar responder esta questão a partir de ECRs publicados até 31/01/2013 no MEDLINE, LILACS, Embase e Registro Cochrane de Ensaios Clínicos Controlados.

Primeiramente, deve-se destacar que somente há três ECRs sobre o efeito dos medicamentos imunomoduladores no tratamento da HAM/TSP. Os ECRs localizados, por sua vez, apresentam tamanho pequeno de amostra e heterogeneidade no tocante aos medicamentos imunomoduladores (interferon $\alpha$, e zidovudina e lamivudina) utilizados como intervenções. Além disso, os desfechos clínicos avaliados foram diferentes nesses ECRs (comprometimento funcional avaliado com escalas diferentes; distúrbio urinário e exames laboratoriais avaliados sem padronização ou sem uso de escalas). Portanto, não pode ser conduzida uma metanálise nesta dissertação. A avaliação da duração do tratamento também não foi enfatizada nesta revisão porque não existem recomendações sobre a duração do tratamento com drogas imunomoduladoras para terapêutica da HAM/TSP.

Dada a falta de estudos de dose-resposta, é incerto se algum dos estudos utilizou a dose ideal. No entanto, os ECRs avaliados destacaram quais foram os desfechos clínicos e as questões metodológicas que necessitariam de padronização e reavaliação para os próximos estudos de intervenção que vierem a ser elaborados. 
Adicionalmente, dos três ECRs localizados, apenas o estudo de Taylor et al. (2006) utilizou placebo no grupo-controle. Nesse trabalho, entretanto, o grupo que recebeu zidovudina e lamivudina não apresentou melhora significativa do comprometimento funcional, da dor em membros inferiores e do distúrbio urinário. Pode-se especular que os fármacos antirretrovirais, tais como a zidovudina e lamivudina, atuariam inibindo a enzima transcriptase reversa viral e bloqueando a replicação viral em linfócitos CD4+ infectados. Entretanto, sabe-se que o aumento da carga proviral do HTLV-1 in vivo ocorre, principalmente, devido à expansão policlonal das células infectadas, via mitose, e não em decorrência da replicação viral propriamente dita, que in vivo parece não ter importância (Nejmeddine; Bangham, 2010; Kress et al., 2011). Ao lado disso, podem-se apresentar limitações de próprio estudo, que incluem longo tempo de sintomatologia (média de 10,5 anos); casuística pequena; e talvez a ocorrência de manifestações diferentes por subtipos virais do HTLV-1, por diversidade genética da população, e alelos HLA classe I do hospedeiro, que podem modular a reposta imunológica e que determinam maior susceptibilade à infecção pelo HTLV-1 e ao adoecimento, dado que os pacientes avaliados por esses estudos vieram de origens étnicas diferentes (descendentes de negros africanos do Caribe, ascendência indígena, japonesa e persa) (Vine et al., 2002; Verdonck et al., 2007; Martin; Taylor, 2011).

Talvez os pacientes oligoassintomáticos com outras manifestações neurológicas classificadas como componentes do complexo neurológico associado ao HTLV-1 (Araujo; Silva, 2006) sejam os mais beneficiados com 
as propostas terapêuticas já conhecidas, se aplicadas precocemente, quando comparados aos pacientes com HAM/TSP já cronicamente instalada.

Somente dois estudos, um de Kuroda et al. (1992) e outro de Izumo et al. (1996), avaliaram, sem grupo-controle com placebo, interferon a humano com as mesmas dosagens de $0,3,1,0$ ou 3,0 milhões de $\mathrm{UI}$, pela via intramuscular, uma vez por dia e durante 28 dias. Entretanto, a metanálise não foi executada para análise dos dados desses estudos porque a amostra e os desfechos clínicos foram heterogêneos. No estudo de Kuroda et al. (1992), os dois pacientes que receberam 3,0 milhões de UI de interferon $\alpha$ apresentaram melhores resultados no comprometimento funcional e no distúrbio urinário durante e após a intervenção, quando comparados ao grupo que recebeu a posologia de 0,3 milhões UI ou 1,0 milhão de UI. No estudo de Izumo et al. (1996), o grupo que recebeu 3,0 milhões de UI de interferon $\alpha$ apresentou melhores resultados no comprometimento funcional tanto na quarta semana de intervenção como quatro semanas após término do tratamento, quando comparados ao grupo que recebeu a posologia de 0,3 milhões de Ul ( $p=0,019$ e $p=0,027$, respectivamente). Não houve diferença estatisticamente significativa entre os pacientes desse grupo com o que recebeu 1,0 milhão de $\mathrm{UI}$, tampouco entre 1,0 milhão de $\mathrm{UI}$ e 0,3 milhões de interferon $\alpha$. Os efeitos adversos ocorreram de acordo com a dose utilizada; contudo, a maioria dos pacientes pode continuar utilizando o interferon $\alpha$ até o término da intervenção proposta. 
Os estudos avaliados nesta revisão sitemática tinham amostras entre quatro e 48 participantes, porém a falta de cálculo do tamanho da amostra nos três ECRs não possibilitou avaliar se tinham ou não o poder estatístico suficiente para detectar eventuais diferenças na resposta à intervenção entre os grupos avaliados.

Para avaliação da qualidade dos ECRs, foi utilizada a classificação de Oxford Centre for Evidence-Based of Medicine e a escala de Jadad. 0 estudo de Izumo et al. (1996) e de Taylor et al. (2006) apresentaram cinco pontos na escala de Jadad (alta qualidade), enquanto o estudo de Kuroda et al. apresentou três pontos. Já pela classificação de Oxford Centre for Evidence-Based of Medicine, o estudo de Izumo et al. e de Kuroda et al. apresentaram evidência $A$ e grau de recomendação $1 C$, enquanto o estudo de Taylor et al. (2006) apresentou A e 1B, respectivamente.

Entende-se que outros ECRs são necessários também para comprovar, eventualmente, o benefício do tratamento com medicamentos imunomoduladores em pacientes com sinais e sintomas subjetivos de outras morbidades que compõem o complexo neurológico associado ao HTLV-1, apesar de não apresentarem integralmente os critérios diagnósticos de HAM/TSP. Falta definir nessa população a dose ideal a ser utilizada e quais os desfechos que devem ser avaliados nesses. Pode-se conjecturar que tais intervenções possam ter espaço nos cuidados desses pacientes.

Portanto, os resultados desta revisão sistemática demonstram não haver evidências conclusivas de benefício clinicamente significativo, nem 
prejuízo do uso desses medicamentos imunomoduladores no tratamento de pacientes com HAM/TSP.

Como as manifestações clínicas associadas ao HTLV-1 são incapacitantes e ainda não dispomos de tratamentos eficazes ou curativos, a contraindicação do aleitamento materno em mulheres portadoras do HTLV deve ser entendida como a principal forma de intervenção consistente a diminuir a transmissão vertical desse retrovírus. Além da contraindicação documentada, há necessidade de fornecimento da fórmula láctea infantil e de outras orientações nutricionais, e abordagem psicológica específica para substituir o aleitamento materno sem prejuízo para o vínculo da mãe com seu filho e para a nutrição do neonato. 


\section{CONCLUSÃo}

Esta revisão sistemática da literatura não pode ser seguida de metanálise devido à heterogeneidade clínica dos ECRs avaliados.

Todavia, após a revisão sistemática, pode-se concluir que:

- Os pacientes que receberam 3,0 milhões de UI de interferon $\alpha$, pela via intramuscular, uma vez por dia, durante 28 dias consecutivos, apresentaram melhora temporária do comprometimento funcional e do distúrbio urinário quando comparados àqueles que receberam outras doses desse fármaco, com efeitos adversos toleráveis e temporários. A intensidade da melhora e o tempo do benefício dependeram do grau de comprometimento funcional e urinário anterior à intervenção;

- Os pacientes que receberam $300 \mathrm{mg}$ de zidovudina e $150 \mathrm{mg}$ de lamivudina, pela via oral, duas vezes por dia, durante 24 semanas, não apresentaram melhora significativa do comprometimento funcional, da dor em membros inferiores ou do distúrbio urinário, quando comparados aos pacientes que receberam placebo;

- Não há evidência definitiva de eficácia do uso interferon a ou zidovudina e lamivudina para o tratamento da HAM/TSP, e não há 
elementos que permitam concluir sobre a eficácia de outras intervenções farmacológicas empregando imunomoduladores. 
7 AnEXOS 


\section{ANEXOS}

ANEXO A - Descrição do estudo.

\section{DESCRIÇÃO DO ESTUDO}

Título:

Autor(s):

Ano de publicação:

Preenchido por:

Quantos pacientes foram incluídos?

Critérios de inclusão:

Critérios de exclusão:

Número de participantes:

Idade:

Sexo:

Diagnóstico:

Gravidade da doença:

Tratamento:

Via de administração:

Dose:

Posologia:

Quais as comparações feitas no estudo?

Duração:

Quais são os desfechos:

Este estudo auxilia na resposta da questão clínica?

Fontes de investimento:

Aprovação ética:

Conflito de interesses dos autores: 
ANEXO B - Avaliação global do estudo.

AVALIAÇÃO GLOBAL DO ESTUDO

\begin{tabular}{|c|c|}
\hline Em um estudo terapêutico & Resposta \\
\hline $\begin{array}{l}\text { 2.1 Quão adequado foi realizado o } \\
\text { estudo para reduzir vieses? } \\
\text { Gradue em }++,+ \text { ou - }\end{array}$ & \\
\hline $\begin{array}{l}2.2 \text { Se graduado + ou - de que } \\
\text { forma os vieses podem afetar os } \\
\text { resultados? }\end{array}$ & \\
\hline $\begin{array}{l}\text { 2.3 Considerando os aspectos } \\
\text { clínicos, a avaliação da metodologia } \\
\text { utilizada e o poder estatístico do } \\
\text { estudo, você está certo de que o } \\
\text { efeito é devido a intervenção? }\end{array}$ & \\
\hline $\begin{array}{l}2.4 \text { Os resultados do estudo são } \\
\text { diretamente aplicáveis ao grupo } \\
\text { alvo de pacientes da tese? }\end{array}$ & \\
\hline
\end{tabular}


ANEXO C - Validade interna.

\section{VALIDADE INTERNA}

\begin{tabular}{|l|l|}
\hline \multicolumn{1}{|c|}{ Em um estudo terapêutico } & Este item pode ser graduado em: \\
\hline apropriada e focal? & ( ) De acordo \\
& ( ) Parcialmente de acordo \\
& ( ) Parcialmente em desacordo \\
& ( ) Em desacordo \\
grupos de tratamento é & ( ) Não relatado \\
randomizada? & ( ) Não aplicável \\
\hline 1.2 A alocação dos pacientes nos & ( ) De acordo \\
alocação vendada foi utilizado? & ( ) Parcialmente de acordo \\
& ( ) Parcialmente em desacordo \\
& ( ) Em desacordo \\
& ( ) Não relatado \\
& ( ) Narcialmente de acordo \\
& ( ) Eão aplicável \\
\hline
\end{tabular}




\begin{tabular}{|l|l|}
\hline f.4 Os pacientes e pesquisadores & ( ) De acordo \\
alocação do tratamento? & ( ) Parcialmente de acordo \\
( ) Parcialmente em desacordo \\
( ) Em desacordo \\
( ) Não relatado \\
( ) Não aplicável
\end{tabular}




\begin{tabular}{|c|c|}
\hline $\begin{array}{l}\text { 1.8 Qual a porcentagem de perdas } \\
\text { em cada grupo? É maior do que } \\
20 \% ?\end{array}$ & \\
\hline $\begin{array}{l}\text { 1.9 Todos os pacientes foram } \\
\text { analisados no grupo para o qual } \\
\text { foram randomizados (análise por } \\
\text { intenção de tratamento)? }\end{array}$ & $\begin{array}{l}\text { ( ) De acordo } \\
\text { ( ) Parcialmente de acordo } \\
\text { ( ) Parcialmente em desacordo } \\
\text { ( ) Em desacordo } \\
\text { ( ) Não relatado } \\
\text { ( ) Não aplicável }\end{array}$ \\
\hline $\begin{array}{l}1.10 \text { O estudo foi conduzido em mais } \\
\text { de um centro e os resultados são } \\
\text { comparáveis por centro de estudo? }\end{array}$ & $\begin{array}{l}\text { ( ) De acordo } \\
\text { ( ) Parcialmente de acordo } \\
\text { ( ) Parcialmente em desacordo } \\
\text { ( ) Em desacordo } \\
\text { ( ) Não relatado } \\
\text { ( ) Não aplicável }\end{array}$ \\
\hline 1.11 Avaliação pela escala de Jadad & \\
\hline $\begin{array}{l}\text { 1.12 Evidência/Grau de } \\
\text { Recomendação segundo a } \\
\text { classificação de Oxford Centre e } \\
\text { Jadad }\end{array}$ & \\
\hline
\end{tabular}




\section{REFERÊNCIAS}




\section{REFERENCIAS}

Abrams A, Akahata Y, Jacobson S. The prevalence and significance of HTLV-I/II seroindeterminate Western blot patterns. Viruses. 2011 Aug;3(8):1320-31.

Araujo AQ, Silva MT. The HTLV-1 neurological complex. Lancet Neurol. 2006 Dec;5(12):1068-76.

Arimura K, Nakagawa M, Izumo S, Usuku K, Itoyama Y, Kira J, Osame M. Safety and efficacy of interferon-alpha in 167 patients with human T-cell lymphotropic virus type 1-associated myelopathy. J Neurovirol. 2007 Aug;13(4):364-72.

Bennett M, Vicenti F, Krensky AM. Imunossupressores, Tolerógenos e Imunoestimulantes. In: As Bases Farmacológicas da Terapêutica. Rio de Janeiro: McGraw - Hill; 2010. p. 1265-1286.

Bernardo WM, Nobre MR, Jatene FB. Evidence-based clinical practice. Part II - Searching evidence databases. Rev Assoc Med Bras. 2004 JanMar;50(1):104-8.

Brasil. Ministério da Saúde. Secretaria de Vigilância em Saúde. Programa Nacional de DST e Aids. Brasília (DF): Guia de Manejo Clínico do Paciente com HTLV. Saúde; 2003.

BVS. Ciências da Saúde em Geral. 2012. Acesso disponível pelo http://regional.bvsalud.org/php/level.php?lang=pt\&component=107\&item =10 7 e realizado no dia $31 / 01 / 13$.

Carod-Artal FJ. Immunopathogenesis and treatment of the myelopathy associated to the HTLV-I virus. Rev Neurol. 2009 Feb;48(3):147-55.

Cartier L, Castillo JL, Verdugo R. Effect of the Nucleus CMP forte in 46 patients with progressive spastic paraparesis. Randomized and blind study. Rev Med Chil. 1996 May;124(5):583-7. 
Castro AA, Saconato H, Guidugli F, Clark OAC. Curso de revisão sistemática e metanálise [Online]. São Paulo: LED-DIS/UNIFESP; 2002. Acesso disponível em: http://www.virtual.epm.br/cursos/metanalise e realizado no dia 31/01/2013.

Casseb J, Penalva-de-Oliveira AC. The pathogenesis of tropical spastic paraparesis/human T-cell leukemia type I-associated myelopathy. Braz J Med Biol Res. 2000 Dec;33(12):1395-401.

Castro-Costa CM, Carton H, Goubau P, de Figueiredo EG, Giffoni SD. Tropical spastic paraparesis in the tropics and Brazil. A historical analysis. Arq Neuropsiquiatr. 1994 Mar;52(1):106-9.

Castro-Costa CM, Carton H, Santos TJ. HTLV-I negative tropical spastic paraparesis: a scientific challenge. Arq Neuropsiquiatr. 2001 Jun;59(2A):289-94 .

Catalan-Soares B, Carneiro-Proietti AB, Proietti FA; Interdisciplinary HTLV Research Group. Heterogeneous geographic distribution of human T-cell lymphotropic viruses I and II (HTLV-I/II): serological screening prevalence rates in blood donors from large urban areas in Brazil. Cad Saude Publica. 2005 May-Jun;21(3):926-31.

Centre for Reviews and Dissemination, University of York. CRD's guidance for undertaking reviews in health care. 3rd ed. York: University of York; 2009. $294 \mathrm{p}$.

Cook DJ, Mulrow CD, Haynes RB. Systematic reviews: synthesis of best evidence for clinical decisions. Ann Intern Med. 1997 Mar;126(5):376-80.

Costa EA, Magri MC, Caterino-de-Araujo A. The best algorithm to confirm the diagnosis of HTLV-1 and HTLV-2 in at-risk individuals from São Paulo, Brazil.J Virol Methods. 2011 May;173(2):280-6.

Croda MG, de Oliveira AC, Vergara MP, Bonasser F, Smid J, Duarte AJ, Casseb J. Corticosteroid therapy in TSP/HAM patients: the results from a 10 years open cohort. J Neurol Sci. 2008 Jun;269(1-2):133-7. 
Duncan J, Rudge P. Methylprednisolone therapy in tropical spastic paraparesis. J Neurol Neurosurg Psychiatry. 1990 Feb;53(2):173-4.

Evidence-Based Medicine Working Group. Evidence-based medicine. A new approach to teaching the practice of medicine. JAMA. 1992 Nov;268(17):2420-5.

Feuer G, Green PL. Comparative biology of human T-cell lymphotropic virus type 1 (HTLV-1) and HTLV-2. Oncogene. 2005 Sep;24(39):5996-6004.

Gout O, Gessain A, Iba-Zizen M, Kouzan S, Bolgert F, de Thé G, Lyon-Caen $\mathrm{O}$. The effect of zidovudine on chronic myelopathy associated with HTLV-1. J Neurol. 1991 Apr;238(2):108-9.

Guyatt GH, Oxman AD, Kunz R, Vist GE, Falck-Ytter Y, Schünemann HJ. What is "quality of evidence" and why is it important to clinicians. BMJ 2008; 336: 994-8.

Higgins JPT, Green S, editors. Cochrane Handbook for Systematic Reviews of Interventions Version 5.1.0 [updated March 2011]. The Cochrane Collaboration; 2011. Available from: www.cochrane-handbook.org.

Igakura T, Stinchcombe JC, Goon PK, Taylor GP, Weber JN, Griffiths GM, Tanaka Y, Osame M, Bangham CR. Spread of HTLV-I between lymphocytes by virus-induced polarization of the cytoskeleton. Science. 2003 Mar;299(5613):1713-6.

Izumo S, Goto I, Itoyama Y, Okajima T, Watanabe S, Kuroda Y, Araki S, Mori M, Nagataki S, Matsukura S, Akamine T, Nakagawa M, Yamamoto I, Osame M. Interferon-alpha is effective in HTLV-I-associated myelopathy: A multicenter, randomized, double-blind, controlled trial. Neurology. 1996;46(4):1016-21.

Jadad AR, Moore RA, Carroll D, Jenkinson C, Reynolds DJ, Gavaghan DJ, McQuay HJ. Assessing the quality of reports of randomized clinical trials: is blinding necessary? Control Clin Trials. 1996 Feb;17(1):1-12.

Kannian P, Green PL. Human T Lymphotropic Virus Type 1 (HTLV-1): Molecular Biology and Oncogenesis. Viruses. 2010 Sep;2(9):2037-77. 
Kress AK, Grassmann R, Fleckenstein B. Cell surface markers in HTLV-1 pathogenesis. Viruses. 2011 Aug;3(8):1439-59.

Kuroda Y, Kurohara K, Fujiyama F, Takashima H, Endo C, Matsui M, Neshige R, Kakigi R. Systemic interferon-alpha in the treatment of HTLV-Iassociated myelopaty. Acta Neurologica Scandinavica. 1992;86(1):82-6.

Kuroda Y, Takashima H, Ikeda A, Endo C, Neshige R, Kakigi R, Shibasaki H. Treatment of HTLV-I-associated myelopathy with high-dose intravenous gammaglobulin. J Neurol. 1991 Sep;238(6):309-14.

Lairmore MD, Anupam R, Bowden N, Haines R, Haynes RA 2nd, Ratner L, Green PL. Molecular determinants of human T-lymphotropic virus type 1 transmission and spread. Viruses. $2011 \mathrm{Jul} ; 3(7): 1131-65$.

Magnus P, Stigum H, Nord E, Bjørndal A, Samdal HH, Skulberg A, Heier HE. Quality adjusted life years in assessment of preventive measures. Should blood donors be tested for HTLV-I/II infections?. Tidsskr Nor Laegeforen. 1996 Apr;116(10):1229-32.

Mahieux R, Gessain A. HTLV-3/STLV-3 and HTLV-4 viruses: discovery, epidemiology, serology and molecular aspects. Viruses. $2011 \mathrm{Jul} ; 3(7): 1074-$ 90.

Marinho J, Galvão-Castro B, Rodrigues LC, Barreto ML. Increased risk of tuberculosis with human T-lymphotropic virus-1 infection: a case-control study. J Acquir Immune Defic Syndr. 2005 Dec;40(5):625-8.

Martin F, Taylor GP. Prospects for the management of human T-cell lymphotropic virus type 1-associated myelopathy. AIDS Rev. 2011 JulSep;13(3):161-70.

Matsuoka M, Jeang KT. Human T-cell leukaemia virus type 1 (HTLV-1) infectivity and cellular transformation. Nat Rev Cancer. 2007 Apr;7(4):270-80.

Melo A, Moura L, Meireles A, Costa G. Danazol. A new perspective in the treatment of HTLV-1 associated myelopathy (preliminary report). Arq Neuropsiquiatr. 1992 Sep;50(3):402-3. 
Mylonas I, Brüning A, Kainer F, Friese K. HTLV infection and its implication in gynaecology and obstetrics. Arch Gynecol Obstet. 2010 Nov;282(5):493-501.

Nagai M, Usuku K, Matsumoto W, Kodama D, Takenouchi N, Moritoyo T, Hashiguchi S, Ichinose M, Bangham CR, Izumo S, Osame M. Analysis of HTLV-I proviral load in 202 HAM/TSP patients and 243 asymptomatic HTLV-I carriers: high proviral load strongly predisposes to HAM/TSP. J Neurovirol. 1998 Dec;4(6):586-93.

Nakagawa M, Nakahara K, Maruyama Y, Kawabata M, Higuchi I, Kubota H, Izumo S, Arimura K, Osame M. Therapeutic trials in 200 patients with HTLVI-associated myelopathy/ tropical spastic paraparesis. J Neurovirol. 1996 Oct;2(5):345-55.

Nejmeddine M, Bangham CR. The HTLV-1 Virological Synapse. Viruses. $2010 \mathrm{Jul} ; 2(7): 1427-47$.

Nobre MR, Bernardo WM, Jatene FB. Evidence based clinical practice. Part 1 - well structured clinical questions. Rev Assoc Med Bras. 2003 OctDec;49(4):445-9.

Oh U, Jacobson S. Treatment of HTLV-I-Associated Myelopathy/Tropical Spastic Paraparesis: Toward Rational Targeted Therapy. Neurologic Clinics. 2008 Aug;26(3):781-97.

Osame M, Usuku K, Izumo S, ljichi N, Amitani H, Igata A, Matsumoto M, Tara M. HTLV-I associated myelopathy, a new clinical entity. Lancet. 1986 May;1(8488):1031-2.

Phillips B, Ball C, Sackett D, Badenoch D, Straus S, Haynes B, Dawes M. Oxford Centre for Evidence-based Medicine Levels of Evidence. 2009. Acesso disponível em: http://www.cebm.net/index.aspx?o=1025 e realizado no dia 31/01/2013.

Poiesz BJ, Ruscetti FW, Gazdar AF, Bunn PA, Minna JD, Gallo RC. Detection and isolation of type $C$ retrovirus particles from fresh and cultured lymphocytes of a patient with cutaneous T-cell lymphoma. Proc Natl Acad Sci USA. 1980 Dec;77(12):7415-9. 
Recommendations for counseling persons infected with human Tlymphotrophic virus, types I and II. Centers for Disease Control and Prevention and U.S. Public Health Service Working Group. MMWR Recomm Rep. 1993 Jun;42(RR-9):1-13.

Review Manager (RevMan) [Computer program]. Version 5.1. Copenhagen: The Nordic Cochrane Centre, The Cochrane Collaboration, 2011.

Ribas JG, Melo GC. [Human T-cell lymphotropic virus type 1(HTLV-1)associated myelopathy]. Rev Soc Bras Med Trop. 2002 Jul-Aug;35(4):37784.

Robinson KA, Saldanha IJ, McKoy NA. Development of a framework to identify research gaps from systematic reviews. J Clin Epidemiol. 2011 Dec;64(12):1325-30.

Roucoux DF, Wang B, Smith D, Nass CC, Smith J, Hutching ST, Newman B, Lee T, Chafets DM, Murphyet EL. A prospective study of sexual transmission of human $T$ lymphotropic virus (HTLV)-I and HTLV-II. J Infect Dis. 2005;191:1490-7.

Saito M, Nakagawa M, Kaseda S, Matsuzaki T, Jonosono M, Eiraku N, Kubota R, Takenouchi N, Nagai M, Furukawa Y, Usuku K, Izumo S, Osame M. Decreased human T lymphotropic virus type I (HTLV-I) provirus load and alteration in $T$ cell phenotype after interferon-alpha therapy for HTLV-Iassociated myelopathy/tropical spastic paraparesis. J Infect Dis. 2004 Jan;189(1):29-40.

Shirabe S, Nakamura T, Tsujino A, Nishiura Y, Furuya T, Goto H, Suenaga A, Nakane S, Yoshimura T, Nagataki S. Successful application of pentoxifylline in the treatment of HTLV-I associated myelopathy. J Neurol Sci. 1997 Oct;151(1):97-101.

Taylor GP, Goon P, Furukawa Y, Green H, Barfield A, Mosley A, Nose H, Babiker A, Rudge P, Usuku K, Osame M, Bangham CR, Weber JN. Zidovudine plus lamivudine in Human T-Lymphotropic Virus type-Iassociated myelopathy: a randomised trial. Retrovirology. 2006 Sep;3:63. 
Uchiyama T, Yodoi J, Sagawa K, Takatsuki K, Uchino H. Adult T-cell leukemia: clinical and hematologic features of 16 cases. Blood. 1977 Sep;50(3):481-92.

Verdonck K, González E, Van Dooren S, Vandamme AM, Vanham G, Gotuzzo E. Human T-lymphotropic virus 1: recent knowledge about an ancient infection. Lancet Infect Dis. 2007;7(4):266-81.

Vine AM, Witkover AD, Lloyd AL, Jeffery KJ, Siddiqui A, Marshall SE, Bunce M, Eiraku N, Izumo S, Usuku K, Osame M, Bangham CR. Polygenic control of human $\mathrm{T}$ lymphotropic virus type I (HTLV-I) provirus load and the risk of HTLV-I-associated myelopathy/tropical spastic paraparesis. J Infect Dis. 2002 Oct;186(7):932-9.

WHO. Report from the Scientific Group on HTLV-I Infection and its Associated Diseases, convened by the Regional Office for the Western Pacific of the World Health Organization in Kagoshima. Weekly Epidemiol Rec. 1989 Dec;49:382-3.

Yamasaki K, Kira J, Koyanagi Y, Kawano Y, Miyano-Kurosaki N, Nakamura M, Baba E, Suzuki J, Yamamoto A, Yamamoto N, Kobayashi T. Long-term, high dose interferon-alpha treatment in HTLV-I-associated myelopathy/tropical spastic paraparesis: a combined clinical, virological and immunological study. J Neurol Sci. 1997 Apr;147(2):135-44. 